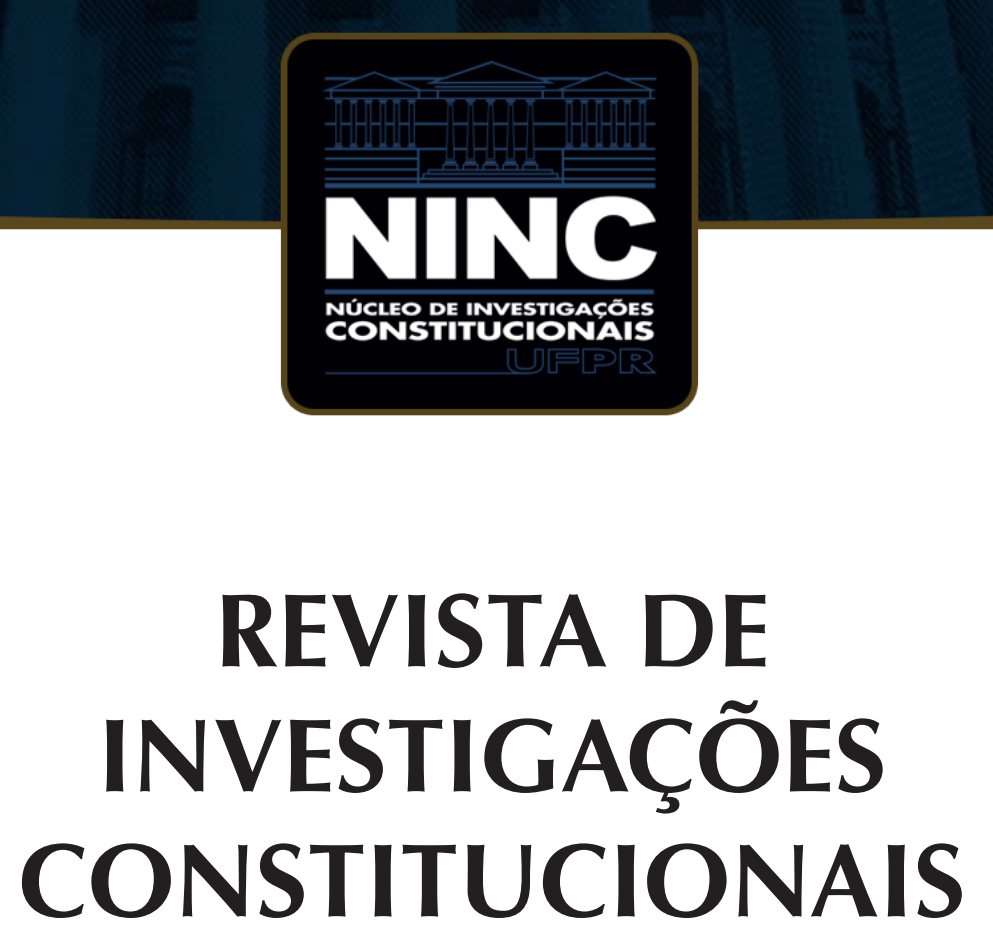

JOURNAL OF CONSTITUTIONAL RESEARCH

vol. 5 | n. 1 | janeiro/abril 2018 | ISSN 2359-5639 | Periodicidade quadrimestral Curitiba | Núcleo de Investigações Constitucionais da UFPR | www.ninc.com.br 


\title{
Separação dos poderes e complexidade social - uma releitura sistêmica
}

\section{Separation of powers and social complexity - a systemic rereading}

\section{FERNANDO RISTER DE SOUSA LIMA*}

Universidade Presbiteriana Mackenzie (Brasil) fernando.lima@mackenzie.br

\section{ORLANDO VILLAS BÔAS FILHO**}

Universidade Presbiteriana Mackenzie (Brasil) Universidade de São Paulo (Brasil)

ovbf@usp.br

Recebido/Received: 08.11.2017 / November 1 $11^{\text {th }}, 2017$ Aprovado/Approved: 31.12.2017 / December 31st, 2017

\begin{abstract}
Como citar esse artigo/How to cite this article: LIMA, Fernando Rister de Souza; VILLAS BÔAS FILHO, Orlando. Separação dos poderes e complexidade social - uma releitura sistêmica. Revista de Investigações Constitucionais, Curitiba, vol. 5, n. 1, p. 189-220, jan./abr. 2018. DOI: 10.5380/rinc.v5i1.56247.

* Professor Doutor da Faculdade de Direito da Universidade Presbiteriana Mackenzie (São Paulo, SP, Brasil). Coordenador do GEPESD/MACK - Grupo de Estudos e Pesquisa em Sociologia do Direito do Mackenzie. Doutor em Filosofia de Direito e do Estado pela Pontifícia Universidade Católica de São Paulo (PUC-SP/2013) com estágio doutoral sanduíche no Departamento de Sociologia da Università degli Studi di Macerata (UNIMC/Itália-CAPES/2012). Pós-Doutorado pelo Departamento de Filosofia e Teoria Geral do Direito da Universidade de São Paulo (DFD/USP-Largo de São Francisco - 2016/2017) com período de pesquisa na Goethe Universität Frankfurt am Main (07/2017). Mestre em Direito pela Pontifícia Universidade Católica de São Paulo (PUC-SP/2007) com período como pesquisador visitante na Università degli Studi di Lecce - Itália (2005). Membro do Research Committee on Sociology of Law - ISA - Group Sociology of Constitution. Editor-Chefe (2013-2016) da Revista Brasileira de Sociologia do Direito (RBSD). Segundo Vice-Presidente (2014-2016) e Conselheiro Fiscal (2012-2014) da Associação Brasileira de Pesquisadores em Sociologia do Direito (ABraSD). E-mail: fernando.lima@mackenzie.br.

** Professor da Faculdade de Direito da Universidade de São Paulo e Professor Associado da Faculdade de Direito da Universidade Presbiteriana Mackenzie (São Paulo, SP, Brasil). Pós-Doutorado na Université de Paris X - Nanterre, França. Pós-Doutorado na École Normale Supérieure de Paris, França. Doutorado em Direito e Mestrado em Direito na área de concentração Filosofia e Teoria Geral do Direito, pela Universidade de São Paulo. Graduação e Licenciatura Plena em História pela Universidade de São Paulo. Graduação em Direito pela Pontifícia Universidade Católica de São Paulo. Graduação em Filosofia pela Universidade de São Paulo. E-mail: ovbf@usp.br.
\end{abstract}


Resumo

O propósito deste artigo é esboçar uma análise sistêmica do princípio da separação dos poderes no contexto da sociedade contemporânea, marcada por sua fragmentação em diversos subsistemas autônomos que exercem funções distintas em um universo hipercomplexo. Para cumprir a tare$\mathrm{fa}$, em primeiro lugar, procura justificar o referencial teórico escolhido mediante a indicação de sua pertinência para o tratamento da questão a ser analisada. Em seguida, realiza uma breve reconstrução do itinerário intelectual da ideia de separação dos poderes na "semântica moderna". Assim, sem pretender realizar uma análise histórica mais consequente dessa ideia, o estudo faz apenas uma alusão a autores clássicos que, no horizonte da "semântica moderna", contribuíram para sua difusão e consolidação. No percurso, o estudo se orienta, especialmente, pela tese de Quentin Skinner, cujo foco consiste em elaborar instrumentos metodológicos adequados para se evitar o anacronismo no âmbito da história das ideias. Por fim, com base na teoria dos sistemas de Niklas Luhmann, propõe uma releitura sistêmica da separação dos poderes.

Palavras-chave: separação dos poderes; teoria dos sistemas; Poder Judiciário; Constituição; diferenciação funcional.

\section{Abstract}

The purpose of this article is to outline a systemic analysis of the principle of separation of powers in the context of contemporary society, marked by its fragmentation in several autonomous subsystems that perform distinct functions in a hypercomplex universe. To accomplish the task, firstly, it seeks to justify the theoretical reference chosen by indicating its relevance to the treatment of the question to be analyzed. Then the article makes a brief reconstruction of the intellectual itinerary of the idea of separation of powers in "modern semantics". Thus, without intending to make a more consistent historical analysis of this idea, the study only refers to classical authors who, in the context of "modern semantics", contributed to its diffusion and consolidation. For doing so, the study is guided, in particular, by the thesis of Quentin Skinner, whose focus is to develop suitable methodological tools to avoid anachronism in the history of ideas. Finally, based on Niklas Luhmann's systems theory, the article proposes a systemic re-reading of the separation of powers.

Keywords: separation of powers; systems theory; judicial power; Constitution; functional differentiation

\section{SUMÁRIO}

1. Introdução; 2. Da pertinência da teoria dos sistemas como referencial analítico para a discussão da separação dos poderes em um contexto hipercomplexo; 3. Separação dos poderes: nota sobre a construção moderna de um conceito político fundamental; 4. Uma releitura sistêmica da separação dos poderes; 5 . Conclusão; 6 . Referências.

"O poder absoluto gera injustiça."

(Dionísio, 4 K-S)

\section{INTRODUÇÃO}

O objetivo deste artigo é esboçar uma análise sistêmica da ideia de separação de poderes no contexto da sociedade contemporânea, marcada por sua fragmentação em diversos subsistemas autônomos que exercem funções distintas em um universo hipercomplexo. Para tanto, em primeiro lugar, procura justificar o referencial teórico escolhido mediante a indicação de sua pertinência para o tratamento da questão a ser analisada. Assim, conforme se mostrará a seguir, a teoria dos sistemas, quando comparada a outras propostas teóricas de grande potencial analítico, é especialmente vocacionada à análise da separação dos poderes porque, inscrevendo-se no âmbito de uma importante matriz sociológica da modernidade, dá especial relevo à diferenciação 
social na configuração da sociedade moderna. Em virtude dessa ênfase na diferenciação, a teoria dos sistemas se afigura como horizonte fértil para a análise da separação dos poderes, pois justamente insiste na contextura fragmentária da sociedade hodierna e, portanto, mostra-se particularmente sensível aos problemas que lhe são atinentes.

Em seguida, o artigo realiza uma breve reconstrução do itinerário intelectual da ideia de separação de poderes na "semântica moderna". Assim, sem pretender, evidentemente, realizar um exame histórico mais consequente dessa ideia, o que seria incompatível com as dimensões e com os propósitos desta análise, procurar-se-á apenas implementar uma alusão a autores clássicos que, no horizonte da "semântica moderna", contribuíram para sua difusão e consolidação. Neste momento, serão enfocadas algumas perspectivas da história das ideias, especialmente a tese de Quentin Skinner, cujo foco consiste em elaborar instrumentos metodológicos adequados para se evitar o anacronismo.

Por fim, para a implementação da releitura sistêmica da separação dos poderes, serão pontuados alguns aspectos da teoria desenvolvida por Niklas Luhmann que, como se sabe, fornece um sofisticado instrumental analítico para a abordagem da complexidade que caracteriza a sociedade contemporânea. Neste sentido, será enfocada, especialmente, a relação entre os subsistemas jurídico e político no âmbito de um contexto social que, tal como o moderno, é marcado pela diferenciação. Para tanto, será especialmente abordado o papel da constituição como forma de acoplamento estrutural e de fechamento do circuito autopoiético desses dois subsistemas funcionais da sociedade moderna.

A propósito, cabe notar que interpretar o Direito é função essencial devido a sua importância para o operador jurídico e para a certeza da aplicação da justiça. Nesse contexto, a separação dos poderes se afigura um tema bastante atual, especialmente diante de um cenário de judicialização que o considera, tal como ocorre no Brasil, desnecessário, fora de moda, quase que impeditiva da concretude normativa. ${ }^{1}$ Desconsidera-se, nessa perspectiva, que o Estado liberal se alicerçou sobretudo no controle do soberano e na garantia das liberdades individuais. Para tanto, dividiu o poder do soberano em três partes, revelando o propósito de isolamento de um poder em face de outro, quer dizer: entre eles, pouco ou nada deveria haver de contato e cada um com a sua função claramente definida. Essa construção, vinculada a Montesquieu, ao menos nesses moldes, fomentou o fortalecimento do Estado liberal mediante, inclusive,

\footnotetext{
1 O vocábulo "judicialização", que impera na discussão brasileira para indicar o processo de progressiva expansão do poder judicial, tanto na esfera política como na social, provém, de inglês judicialization e encontra sua inspiração mais direta em autores como, por exemplo, Mauro Cappelletti, Ran Hirschl, Antoine Garapon e, especialmente, Chester Neal Tate e Torbjörn Vallinder. A respeito, ver, por exemplo: MACIEL, Débora Alves; KOERNER, Andrei. Sentidos da judicalização da política: duas análises. Lua Nova, n. 57, p. 113-133, 2002. Acerca da discussão francesa, focalizando especialmente a "sociologia política do direito", ver: VILLAS BÔAS FILHO, Orlando. A juridicização e a judiciarização enfocadas a partir da "sociologia política do direito" de Jacques Commaille. Revista brasileira de sociologia do direito, vol. 2, n. 2, p. 56-75, 2015.
} 
a mistificação da sua proposta de divisão. ${ }^{2}$ Entretanto, não foi sempre esse o ideário dominante no que diz respeito à precitada "separação de poderes" 3 . Assim, no contexto do Brasil atual, cabe indagar qual a utilidade da separação dos poderes, no processo de construção de sentido da norma jurídica pelo judiciário.

\section{DA PERTINÊNCIA DA TEORIA DOS SISTEMAS COMO REFEREN- CIAL ANALÍTICO PARA A DISCUSSÃO DA SEPARAÇÃO DOS PO- DERES EM UM CONTEXTO HIPERCOMPLEXO}

A escolha de um referencial teórico para análise de qualquer temática complexa sempre demanda justificativa. Por esse motivo, o presente estudo se inicia com a justificativa da pertinência do referencial escolhido para o tratamento do princípio da separação de poderes. Essa justificativa é particularmente importante porque, como ressalta Guibentif, as diversas propostas teóricas desenvolvidas na atualidade caracterizar-se-iam pela pretensão de suas "garantias de pertinência" relativamente à análise da realidade. 4 Contudo, a teoria dos sistemas, ao conceber a sociedade moderna a partir do tipo de diferenciação primária que a estrutura, tende a fornecer um quadro analítico especialmente adequado para a análise das questões atinentes à separação dos poderes. Para que se explicite, em termos mais evidentes, essa pertinência do referencial relativamente à temática em questão, a seguir será realizada uma breve análise da inscrição da teoria dos sistemas de Niklas Luhmann no âmbito da matriz sociológica da "diferenciação social", nos termos em que Danilo Martuccelli a define.

A modernidade, enquanto objeto da análise sociológica, teria sido descrita por variados autores a partir de diferentes maneiras, decorrendo daí a sua significativa porosidade conceitual. 5 Para a reconstrução e a articulação das diversas abordagens sociológicas desenvolvidas acerca desse tema, Martuccelli propõe a utilização do conceito de matriz, que consistiria em uma forma de compreensão da continuidade da 2 BONAVIDES, Paulo. Do Estado liberal ao Estado social. 7. ed. 2. tir. São Paulo: Malheiros, 2004, p. 44-45. Sobre a implemen-
tação dos valores liberais pela burguesia e a separação dos poderes como artefato desse pleito, ver WOLKMER, Antonio Carlos.
História do direito no Brasil. 4. ed. Rio de Janeiro: Forense, 2007, p. 92-93, CAMPILONGO, Celso Fernandes. Política, sistema
jurídico e decisão judicial. São Paulo: Max Limonad, 2002, p. 34, 36-37, MACIVER, R. M. The modern State. London: Oxford Uni-
versity Press, 1964, p. 364-395; GRAU, Eros Roberto. O direito posto e o direito pressuposto. 3. ed. São Paulo: Malheiros, 2000,
p. 167: “01. A separação dos poderes constitui um dos mitos mais eficazes do Estado liberal, coroado na afirmação, inscrita no
art. 16 das Declaraçães dos Direitos do Homem e do Cidadão, de 1789, [...... Para uma abordagem geral a respeito da separação
dos poderes, na literatura brasileira, ver SALDANHA, Nelson. O Estado moderno e a separação de poderes. São Paulo: Saraiva,
1987, na portuguesa, ver PIÇARRA, Nuno. A separação dos poderes como doutrina e princípio constitucional. Um conjunto
para o estudo das suas origens e evolução. Coimbra: Coimbra, Faculdade de Direito de Lisboa, 1989, na italiana, ver BOGNETTI,
Giovanni. La divisione dei poteri. 2. ed. Milano: Giuffrè, 2001, na espanhola, ver VILE, M.J.C. Contitucionalismo y separación
de poderes. Trad. Joaquín Varela Suanzes-Carpegna. Madrid: Centro de Estudios Políticos y Constitucionales, 2007.

3 Com realce à necessidade de retomada dos estudos históricos sob o enfoque dos conflitos entre os seus atores e, sobretudo, a fim de obter uma nova leitura sob o viés da interdisciplinaridade, ver WOLKMER, Antonio Carlos. História do direito no Brasil... Op. Cit. p. 1.

4 GUIBENTIF, Pierre. Teorias sociológicas comparadas e aplicadas. Bourdieu, Foucault, Habermas e Luhmann face ao direito. Revista Novatio luris, ano II, n. 3, p. 9-33, 2009, p. 19.

5 Cf. MARTUCCELLI, Danilo. Sociologies de la modernité. Paris: Gallimard, 1999. p. 9. 
reflexão sociológica a respeito da modernidade e, por conseguinte, da articulação de suas distintas visões. O conceito de matriz designaria, sobretudo, um espaço de invenção teórica e de descrição da modernidade que não poderia ser reduzido a uma doutrina ou a um único modelo epistemológico consistente. ${ }^{6}$

As três grandes matrizes sociológicas de descrição da modernidade, segundo o mencionado autor, seriam: a) "matriz da diferenciação social"; b) "matriz da racionalização"; e c) "matriz da condição moderna"7 A "matriz da diferenciação social", que privilegia o processo de diferenciação da sociedade como forma de descrição da modernidade, estaria estruturada no pensamento de Émile Durkheim, agregando autores como Talcott Parsons, Pierre Bourdieu e Niklas Luhmann.8 A "matriz da racionalização" - que tem como esteio as obras de Max Weber, Norbert Elias, Herbert Marcuse, Michel Foucault e Jürgen Habermas - enfatizaria, ainda que por perspectivas diferentes e muitas vezes conflitantes, o processo de racionalização como fator definidor do perfil da modernidade. Nesse contexto, mesmo divergindo significativamente, as propostas de Weber, Elias, Marcuse, Foucault e Habermas teriam em comum a problemática da racionalização como pano de fundo de suas análises sobre a modernidade. ${ }^{9}$ Por fim, na "matriz da condição moderna", a reflexão sociológica estaria voltada à análise dos paradoxos e das contradições insuperáveis da vida moderna - pautada pela fugacidade e efemeridade engendradas por uma condição de constante mutabilidade - cujo ritmo se torna cada vez mais acelerado. Nessa matriz, o foco da análise estaria dirigido acima de tudo para a natureza da relação social que o indivíduo (que não pode mais ser definido como o sujeito coerente e homogêneo da consciência clássica) mantém com um mundo que se tornou fragmentário, como articulam Georg Simmel, Erving Goffman, Alain Touraine e Anthony Giddens. ${ }^{10}$

\footnotetext{
${ }^{6}$ Cf. MARTUCCELLI, Danilo. Sociologies de la modernité... Op. Cit. p. 20-21. Para uma análise da proposta de Martuccelli, ver: VILLAS BÔAS FILHO, Orlando. Teoria dos sistemas e o direito brasileiro. São Paulo: Saraiva, 2009, p. 55-58; VILLAS BÔAS FILHO, Orlando. $O$ direito na teoria dos sistemas de Niklas Luhmann. São Paulo: Max Limonad, 2006, p. 43-44, nota 55; VILLAS BÔAS FILHO, Orlando. Différentiation fonctionnelle. In: ARNAUD, André-Jean (Dir.). Dictionnaire de la globalisation - Droit, science politique, sciences sociales. Paris: LGDJ, 2010, p. 144-148; VILLAS BÔAS FILHO, Orlando. A sociologia do direito: o contraste entre a obra de Émile Durkheim e a de Niklas Luhmann. Revista da Faculdade de Direito da USP, São Paulo, v. 105, p. 565-563, jan./ dez. 2010; GONÇALVES, Guilherme Leite; VILLAS BÔAS FILHO, Orlando. Teoria dos sistemas sociais: direito e sociedade na obra de Niklas Luhmann. São Paulo: Saraiva, 2013, p. 79-80.

7 Vale notar que Martuccelli também alude aos discursos críticos que se delineiam como "contrapontos da modernidade", em meio aos quais sublinha duas tendências: 1- a sociologia e a narrativa da história; 2 - as críticas pós-modernas. Cf. MARTUCCELLI, Danilo. Sociologies de la modernité... Op. Cit. p. 547-562.

8 Cf. MARTUCCELLI, Danilo. Sociologies de la modernité... Op. Cit. p. 29-184.

9 Cf. MARTUCCELLI, Danilo. Sociologies de la modernité... Op. Cit. p. 187-366.

10 Cf. MARTUCCELLI, Danilo. Sociologies de la modernité... Op. Cit. p. 369-537.
} 


\section{Quadro 1}

\section{Matrizes sociológicas da modernidade ${ }^{11}$}

\begin{tabular}{|c|c|c|c|}
\hline $\begin{array}{c}\text { Matrizes da } \\
\text { sociologia }\end{array}$ & $\begin{array}{c}\text { Matriz } \\
\text { sociológica da } \\
\text { "racionalização" }\end{array}$ & $\begin{array}{c}\text { Matriz sociológica } \\
\text { da "diferenciação } \\
\text { social" }\end{array}$ & $\begin{array}{c}\text { Matriz sociológica } \\
\text { da "condição } \\
\text { moderna" }\end{array}$ \\
\hline $\begin{array}{c}\text { Preocupação } \\
\text { essencial da análise }\end{array}$ & $\begin{array}{c}\text { Processo de } \\
\text { racionalização } \\
\text { social }\end{array}$ & $\begin{array}{c}\text { Diferenciação da } \\
\text { sociedade }\end{array}$ & $\begin{array}{c}\text { Paradoxos e } \\
\text { contradições da } \\
\text { vida moderna }\end{array}$ \\
\hline $\begin{array}{c}\text { Descrição da } \\
\text { modernidade }\end{array}$ & $\begin{array}{c}\text { Sociedade } \\
\text { "desencantada" }\end{array}$ & $\begin{array}{c}\text { Funcionalmente } \\
\text { diferenciada }\end{array}$ & $\begin{array}{c}\text { Mundo social } \\
\text { fragmentário e em } \\
\text { constante mutação }\end{array}$ \\
\hline fundamentais & $\begin{array}{c}\text { Max Weber, } \\
\text { Norbert Elias, } \\
\text { Herbert Marcuse, } \\
\text { Michel Foucault e } \\
\text { Jürgen Habermas }\end{array}$ & $\begin{array}{c}\text { Talcott Parsons, } \\
\text { Pierre Bourdieu e } \\
\text { Niklas Luhmann }\end{array}$ & $\begin{array}{c}\text { Alain Touraine e } \\
\text { Erving Goffman, } \\
\text { Anthony Giddens }\end{array}$ \\
\hline
\end{tabular}

Fonte: Gonçalves; Villas Bôas Filho, 2013, p. 80.

Essa sucinta alusão à análise de Martuccelli acerca das matrizes sociológicas da modernidade objetiva sublinhar não apenas a inscrição da teoria dos sistemas de Luhmann no âmbito da matriz da diferenciação social, mas também a importância que a questão da diferenciação assume no âmbito de sua análise da modernidade. Na teoria luhmanniana, a questão da diferenciação é alçada a um patamar de primeira importância, ou seja, é tomada como critério fundamental de definição do perfil da sociedade moderna. Aliás, segundo Martuccelli, em Luhmann essa questão assume uma radicalidade que não encontra paralelo nas demais teorias que compõem a matriz sociológica da diferenciação funcional. Ora, à medida que a teoria dos sistemas dá especial relevo à diferenciação ela se vocaciona especialmente ao tratamento das questões atinentes à separação de poderes, mostrando-se, portanto, um referencial de forte potencial heurístico para a tematização de tal questão.

11 Este quadro foi originalmente publicado em: GONÇALVES, Guilherme Leite; VILLAS BÔAS FILHO, Orlando. Teoria dos sistemas sociais: direito e sociedade na obra de Niklas Luhmann, p. 80. 


\section{SEPARAÇÃO DOS PODERES: NOTA SOBRE A CONSTRUÇÃO MO- DERNA DE UM CONCEITO POLÍTICO FUNDAMENTAL}

A análise de uma formulação teórica de grande impacto, como é o caso da separação dos poderes, implica alguma contextualização. Contudo, evidentemente, não é possível realizar, no âmbito do presente artigo, uma abordagem mais consequente do itinerário intelectual percorrido por essa formulação. Assim, tendo em mente a necessidade de evitar anacronismos grosseiros, a presente análise, em termos bastante circunscritos, focará a inscrição dessa formulação no âmbito da filosofia política moderna. Esse recorte é particularmente importante para elidir projeções anacrônicas que projetam para épocas passadas formulações que nelas não poderiam existir em virtude de estarem ligadas a experiências modernas. ${ }^{12}$ Então, com a finalidade de sublinhar a importância da contextualização das ideias, será feita uma apropriação pontual da perspectiva analítica de Quentin Skinner, autor que procura forjar instrumentos metodológicos para lidar com o problema do anacronismo no âmbito da história das ideias. ${ }^{13}$

Ao reunir algumas perspectivas metodológicas atuais que, no âmbito da análise histórica, têm por objeto o pensamento político, social e respectivos conceitos, Jasmin (2005) aponta duas vertentes fundamentais: de um lado, o contextualismo linguístico, também denominado de "Escola de Cambridge" ou de "enfoque collingwoodiano", cujo principal representante é Quentin Skinner; de outro, a chamada história dos conceitos (Begriffsgeschichte), que tem Reinhart Koselleck como principal expoente. Ambas as perspectivas partem de pressupostos significativamente diversos, mas, malgrado suas divergências, têm, sob vários aspectos, confluído crescentemente para

\footnotetext{
12 Historicamente é pouco viável identificar, com segurança, o momento temporal em que ocorreu a primeira menção literária à separação dos poderes. Obviamente, como ressaltado antes, não é o problema proposto a ser enfrentado aqui. Não obstante, é possível indicar uma preocupação com essa questão no âmbito da filosofia aristotélica, especialmente no que tange à ideia de constituição mista. Todavia, o ideário aristotélico voltou-se muito mais ao espeque social, de sorte a atender à quantidade de governantes existentes. Desse modo, procurando evitar assertivas e interpretações anacrônicas relativamente ao pensamento de Aristóteles, é possível afirmar, em termos genéricos, que ele focalizou o justo meio, ou seja, o equilíbrio, até pela razão de tal proceder ser o grande norte da sua filosofia, quando pensou em poderes que seriam encarregados de gerir a pólis, a magistratura e a administração da justiça A respeito, ver, por exemplo: PIÇARRA, Nuno. A separação dos poderes como doutrina e princípio constitucional, 1989, p. 31-36. GRAU, Eros Roberto. O direito posto e o direito pressuposto, p. 168: "Aristóteles (1982/316; IV 14) ensaia princípios análogos àqueles sobre os quais, posteriormente, se apoia a doutrina do equilíbrio entre os poderes, ao afirmar a existência, nos governos, de três partes.[...]". Ver SILVA, José Afonso da. Curso de direito constitucional positivo. 29. ed. São Paulo: Malheiros, 2007, p. 109.

13 Para uma análise mais profunda das propostas de Quentin Skinner e de Reinhart Koselleck, ver: VILLAS BÔAS FILHO, Orlando. A historicidade da dogmática jurídica: uma abordagem a partir da Begriffsgeschichte de Reinhart Koselleck. In: RODRIGUEZ, José Rodrigo.; SILVA E COSTA, Carlos Eduardo Batalha; BARBOSA, Samuel Rodrigues (Orgs.). Nas fronteiras do formalismo: a função social da dogmática jurídica hoje. São Paulo: Saraiva, 2010, p. 27-61; VILLAS BÔAS FILHO, Orlando. Direito e liberdade: algumas considerações acerca de uma abordagem atenta à historicidade dos conceitos. In: BITTAR, Eduardo Carlos Bianca; ADEODATO, João Maurício (Orgs.). Filosofia e teoria geral do direito: homenagem a Tercio Sampaio Ferraz Junior. São Paulo: Quartier Latin, 2011, p. 917-941; VILLAS BOAS FILHO. Democracia: a polissemia de um conceito político fundamental. Revista da Faculdade de Direito da USP. Vol. 108, p. 651-696, jan./dez. 2013.
} 
posicionamentos cada vez mais próximos. ${ }^{14}$ No presente artigo, será feita alusão à perspectiva de Skinner, considerado o exemplo paradigmático da "Escola de Cambridge".15

Visando rejeitar abordagens históricas simplificadoras acerca do pensamento político que conduziriam a anacronismos inaceitáveis e à pressuposição de que existiria um conjunto de questões perenes (a set of perennial questions) a impulsionar o pensamento político, Skinner procurou uma metodologia de análise histórica que visava dois objetivos fundamentais: a) revisar abordagens anacrônicas que projetam expectativas do presente sobre autores do passado, de modo a considerá-los figuras centrais e representantes de doutrinas ainda não propostas na época em que publicavam seus estudos; b) apropriar-se de uma teoria capaz de fundamentar essa opção metodológica em termos consistentes para a realização de análise histórica acerca da produção do significado em seu respectivo contexto, com a consequente eliminação dos problemas que decorrem do anacronismo. ${ }^{16}$ No que concerne ao primeiro objetivo - revisar abordagens passadas -, Skinner procurou justamente descentrar a análise do pensamento político de seus autores clássicos ${ }^{17}$ e a intenção será desmistificar o que chamou de "mitologias" (mythologies) da história do pensamento que, segundo ele, desdobrar-se-iam basicamente em quatro ramificações: a) a "mitologia das doutrinas" (mythology of doctrines), consistente em considerar determinados autores como representantes de dou-

\footnotetext{
14 Ao longo do tempo, Skinner, em um primeiro momento chegou a postular a impossibilidade de se fazer uma história conceitual, teria progressivamente se aproximado da Begriffsgeschichte, a ponto de afirmar, no texto intitulado Contributions to the History of Concepts, que sua atividade e também a de seus colegas de Cambridge, seriam expressão de uma forma de história conceitual. A respeito, ver: JASMIN, Marcelo Gantus; FERES Jr., João. História dos conceitos: dois momentos de um encontro intelectual. In: ; . (Org.). História dos conceitos: dois momentos de um encontro intelectual: debates e perspectivas. Rio de Janeiro: Ed. da PUC-Rio: Edições Loyola: IUPERJ, 2006, p. 9-38. Ao analisar o confronto da "Escola de Cambridge" com a Begriffsgeschichte, Sandro Chignola distingue o modo pelo qual Skinner e Pocock se relacionam com a perspectiva de Koselleck. Para aquele autor: "Em uma primeira fase, Skinner, contra Raymond Williams, sustentava veementemente a 'impossibilidade' epistemológica de escrever uma 'história dos conceitos'. Posteriormente, essa posição foi sendo substituída por uma outra na qual Skinner admite uma menor incomunicabilidade entre o seu projeto teórico e o de Koselleck. Mais rígido, Pocock tem, ao contrário, uma posição própria: a dimensão 'conceito' não pertence ao discurso político e ao modo como os atores históricos concretos operam este discurso." (CHIGNOLA, Sandro. História dos conceitos e história da filosofia política. In: FERES Jr., João; JASMIN, Marcelo Gantus. (Org.) História dos conceitos: diálogos transatlânticos. Rio de Janeiro: Ed. da PUC-Rio: Edições Loyola: IUPERJ, 2007. p. 48). VILLAS BÔAS FILHO, Orlando. A historicidade da dogmática jurídica: uma abordagem a partir da Begriffsgeschichte de Reinhart Koselleck. In: RODRIGUEZ, José Rodrigo.; SILVA E COSTA, Carlos Eduardo Batalha; BARBOSA, Samuel Rodrigues (Orgs.). Nas fronteiras do formalismo: a função social da dogmática jurídica hoje. São Paulo: Saraiva, 2010, p. 27-61.

15 Vários são os autores que enfatizam a proeminência de Skinner no âmbito da "Escola de Cambridge". Ver, por exemplo: JASMIN, Marcelo Gantus. História dos conceitos e teoria política e social: referências preliminares. Revista brasileira de ciências sociais, São Paulo, v. 20, n. 57, p. 27-38, fev. 2005; FERES Jr., João; JASMIN, Marcelo Gantus. (Org.) História dos conceitos: diálogos transatlânticos. Rio de Janeiro: Ed. da PUC-Rio: Edições Loyola: IUPERJ, 2007; TUCK, Richard. História do pensamento político. In: BURKE, Peter. (Org.) A escrita da história: novas perspectivas. Trad. Magda Lopes. São Paulo: Ed. da Universidade Estadual Paulista, 1992. p. 273-289; e CHIGNOLA, Sandro. História dos conceitos e história da filosofia política. In: FERES Jr., João; JASMIN, Marcelo Gantus. (Org.) História dos conceitos: diálogos transatlânticos. Rio de Janeiro: Ed. da PUC-Rio: Edições Loyola: IUPERJ, 2007. p. 45-57.
}

16 JASMIN, Marcelo Gantus; FERES Jr., João. História dos conceitos: dois momentos de um encontro intelectual. In: (Org.). História dos conceitos: debates e perspectivas. Rio de Janeiro: Ed. da PUC-Rio: Edições Loyola: IUPERJ, 2006, p. 9-38.

17 Nesse particular, entende-se todo o esforço desenvolvido por Skinner em textos como "Fundações do pensamento político moderno". Nesse livro, ressalta que entre os três objetivos que animam esta obra, o terceiro consistiria justamente em "ilustrar um certo modo de proceder ao estudo e interpretação dos textos históricos." E completa: "[...] tentei, assim, escrever uma história menos concentrada nos clássicos e mais na história das ideologias, tendo por objetivo construir um quadro geral no qual possam ser situados os textos teóricos mais proeminentes da política." SKINNER, Quentin. Fundações do pensamento político moderno. Trad. Renato Janine Ribeiro e Laura Teixeira Motta. São Paulo: Companhia das Letras, 1996, p. 10. 
trinas que nada mais são do que projeções do presente sobre o passado, desconsidera, assim, as articulações linguísticas próprias de cada período e, em seu entendimento, responsáveis por animar as ações políticas18; b) a "mitologia da coerência" (mythology of coherence) denota a imposição de uma coerência que não existe originalmente na obra dos autores; c) a "mitologia da prolepse" (mythology of prolepsis) se refere à indevida atribuição de valor histórico antecipado às contribuições intelectuais de um determinado autor; d) a mitologia do paroquialismo (mythology of parochialism) consiste em dotar elementos estranhos e próprios das doutrinas analisadas de uma certa familiaridade que eles não têm. Essas mitologias comporiam o que Skinner denomina de "tipologia do anacronismo" (typology of anachronistic)19, que deve ser combatida, porquanto incumbiria ao historiador ter em mente os conceitos que ainda são invocados nos termos em que foram inicialmente definidos, os seus propósitos e a concepção de poder público que lhes deu sustentação. 20

A atenção do historiador implicaria considerar não apenas as continuidades (continuities), muitas vezes artificialmente criadas, de modo a conceber o passado como uma espécie de espelho (past as a mirror) cuja finalidade seria refletir novamente sobre nossas próprias suposições e preconceitos. Além disso deveria, também, voltarse para as descontinuidades (discontinuities) que permitiriam evidenciar como valores petrificados podem dissolver-se no ar. ${ }^{21}$ Assim, segundo Skinner, em alusão superficial ao pensamento de Foucault, poder-se-ia afirmar que o historiador agiria como uma espécie de arqueólogo pronto para trazer à superfície tesouros intelectuais enterrados de modo a permitir que se reavalie as suas significações. $22 \mathrm{O}$ passado, nessa perspectiva, não é um repositório de conhecimentos direcionados ao auxílio da resolução de problemas do presente. O passado pode fornecer informações relevantes que, entretanto, não são diretamente aplicáveis e devem, isto sim, ser "ruminadas".23 Nesse sentido, é possível afirmar que "a crítica de Skinner se dirige contra toda e qualquer interpretação

\footnotetext{
18 Segundo o autor: "[...] a fim de explicarmos por que tal agente faz o que faz, será preciso referirmo-nos a seu vocabulário, já que este com toda a evidência se delineia como um dos fatores a determinar sua ação." SKINNER, Quentin. Fundações do pensamento político moderno... Op. Cit. p. 12.

19 Acerca das "mitologias" da história do pensamento, apontadas por Skinner, ver: JASMIN, Marcelo Gantus; FERES Jr., João. História dos conceitos: dois momentos de um encontro intelectual. In: perspectivas. Rio de Janeiro: Ed. da PUC-Rio: Edições Loyola: IUPERJ, 2006, p. 15 (Org.). História dos conceitos: debates e

20 SKINNER, Quentin. Liberty before liberalism. Cambridge: Cambridge University Press, 2000, p. 111.

21 SKINNER, Quentin. Liberty before liberalism.Cambridge: Cambridge University Press, 2000, p. 112.

22 Ao comparar o historiador ao arqueólogo, imputando-lhe a função de "bringing buried intellectual treasure back to the surface, dusting it down and enabling us to reconsider what we think of it", Skinner reconhece a superficialidade de sua apropriação do pensamento de Foucault ao afirmar que "my references to archaeology invoke a more commonplace understanding of the term than the one employed by Michel Foucault [...]."SKINNER, Quentin. Liberty before liberalism. Cambridge: Cambridge University Press, 2000, p. 112.

23 SKINNER, Quentin. Liberty before liberalism. Cambridge: Cambridge University Press, 2000, p. 118. O autor utiliza o termo "ruminar" aludindo ao sentido que Nietzsche Ihe teria dado na obra "Genealogia da moral".
} 
histórica que impõe aos autores do passado problemas e linguagens que são exclusivos do presente do estudioso" 24 .

Quanto ao segundo objetivo - apropriação de teoria capaz de elidir os anacronismos decorrentes das análises tradicionais -, Skinner propõe analisar como ocorre a produção do significado a partir do uso da linguagem. Para tanto, apropria-se da teoria dos "atos de fala" (speech acts) desenvolvida por John L. Austin e John R. Searle para enfatizar justamente o caráter performativo da linguagem 25 , ou seja, o fato de que, por intermédio dela, agimos. Assim, tomando como pressuposto a "pluridimensionalidade" dos atos de fala, também proposto por Austin, para demonstrar que, por meio do ato ilocucionário (illocutionary act), nós agimos usando a linguagem, Skinner pretende sustentar que a força ilocucionária de um determinado proferimento (utterance) não é captada apenas pela análise do texto, demandando o conhecimento da intenção de quem o proferiu. 26

Neste ponto do estudo, não cabe recuperar o desenvolvimento em profundidade da proposta metodológica de Skinner, nem as dificuldades que nela remanescem, a despeito de reformulações ou críticas que lhe são dirigidas. O que importa é explicitar a importância de se evitar o anacronismo das abordagens históricas tradicionais, recorrentes nas análises jurídicas, pois, como anota Jasmin, um dos resultados fundamentais da perspectiva de Skinner é justamente a "afirmação da impossibilidade de transposição dos conceitos antigos para o presente sem anacronismo"27. Aliás, conforme ressalta Skinner, os historiadores devem direcionar seus esforços para a finalidade de "reconstruir sem anacronismo as mentalidades de outros períodos. 28

\footnotetext{
24 JASMIN, Marcelo Gantus; FERES Jr., João. História dos conceitos: dois momentos de um encontro intelectual. In: (Org.). História dos conceitos: debates e perspectivas. Rio de Janeiro: Ed. da PUC-Rio: Edições Loyola: IUPERJ, 2006, p. 25.

25 Referindo-se atos de fala performativos, Manfredo Araújo Oliveira ressalta: “[...] a esse tipo de expressão linguística Austin chama de 'performativas' (do verbo inglês to perform) precisamente para distingui-las das proposições comumente consideradas - aquelas que exprimem um ato de constatação -, pois a própria designação executa uma ação. Tais expressões não descrevem fatos, mas 'constituem' fatos, isto é, ações executadas pelo sujeito que as profere." OLIVEIRA Manfredo Araújo de. Reviravolta linguístico-pragmática na filosofia contemporânea. São Paulo: Loyola, 1996, p. 152.
}

26 A respeito, vale notar que a perspectiva de Skinner, embora possa "ser aproximada de outras abordagens contextualistas da primeira metade do século XX - como as propostas, por exemplo, pela noção de utensilagem mental de Lucien Febvre ou da 'sociologia do conhecimento' de Karl Mannheim -, ela traz consigo aquisições da filosofia da linguagem de Wittgenstein e da linguagem ordinária de John Austin" JASMIN, Marcelo Gantus. História dos conceitos e teoria política e social: referências preliminares. Revista Brasileira de Ciências Sociais. v. 20, n. 57, p. 27-38, fev. 2005.

27 JASMIN, Marcelo Gantus. História dos conceitos e teoria política e social: referências preliminares. Revista brasileira de ciências sociais, São Paulo, v. 20, n. 57, fev. 2005, p. 30. Porém, cumpre notar que uma perspectiva como a de Skinner seria metodologicamente limitadora, pois não permitiria aquilatar o nexo do conceito de dogmática jurídica em seus múltiplos usos históricos. É por essa razão que "História dos conceitos" (Begriffsgeschichte) de Reinhart Koselleck pode ser considerada mais sofisticada e consequente. A respeito, ver, especialmente, VILLAS BÔAS FILHO, Orlando. A historicidade da dogmática jurídica: uma abordagem a partir da Begriffsgeschichte de Reinhart Koselleck. In: RODRIGUEZ, José Rodrigo.; SILVA E COSTA, Carlos Eduardo Batalha; BARBOSA, Samuel Rodrigues (Orgs.). Nas fronteiras do formalismo: a função social da dogmática jurídica hoje. São Paulo: Saraiva, 2010, p. 27-61; VILLAS BÔAS FILHO, Orlando. Direito e liberdade: algumas considerações acerca de uma abordagem atenta à historicidade dos conceitos. In: BITTAR, Eduardo Carlos Bianca; ADEODATO, João Maurício (Org.). Filosofia e teoria geral do direito: homenagem a Tercio Sampaio Ferraz Junior. São Paulo: Quartier Latin, 2011, p. 917-941; VILLAS BÔAS FILHO, Orlando. Democracia: a polissemia de um conceito político fundamental. Revista da Faculdade de Direito da USP, São Paulo, vol. 108, p. 651-696, jan./dez. 2013.

28 Conforme Skinner, o propósito seria "reconstruct without anachronism the alien mentalités of earlier periods SKINNER, Quen- 
Sem adentrar as complexas discussões que, no âmbito da pesquisa histórica, gravitam sobre essa questão, não é demais associar o embrião da doutrina denominada "liberalismo" ao debate político-filosófico inglês a desembocar na Carta Magna de 1215, quando se garantiu a proteção à propriedade, ao livre comércio e à liberdade dos súditos. A partir desse momento histórico, tais direitos só poderiam ser atacados após julgamento realizado com base nas leis do respectivo país. No que diz respeito à tripartição de poderes, Locke atribui ares de continuidade à limitação do poder, numa abordagem romântica e teórica, registre-se, posta pelo filósofo, até mesmo de forma abstrata, mormente porque ventilou tolher o poder pelo consentimento, pelo direito natural e pela virtude do governante. Sem embargo, é importante consignar a inegável importância de Locke para o fortalecimento do regime liberal, cujo alicerce inicial se embasou em seus preceptivos, grafados notadamente na obra intitulada "Dois Tratados sobre o Governo Civil". Conhecido como "pai do liberalismo moderno", a obra do filósofo inglês contribuiu para a eclosão das revoluções liberais da Europa e da América, apesar de seu conjunto doutrinário conter fundamentação essencialmente teórica. ${ }^{29}$

Locke parte do estado de natureza do homem para paulatinamente desenvolver um plexo racional, a fim de justificar, ou mesmo ratificar, a propriedade. $30 \mathrm{O}$ estado de natureza, concebido como situação originária que reinaria a liberdade e a igualdade, foi o mote utilizado pelo filósofo para defender a propriedade arduamente, com esteio no direito natural. 31 Trata-se, portanto, de um teórico jusnaturalista que fomenta o Estado liberal, com a assertiva de que a ordem civil que a ela se opusesse perderia

tin. The idea of negative liberty: philosophical and historical perspectives. In: SKINNER, Quentin; RORTY, Richard; SCHNEEWIND, Jerome B. (eds.). Philosophy in history: essays on the historiography of philosophy. Cambridge: Cambridge University Press, p. 193-221, 1998, p. 202. A respeito, ver: A historicidade da dogmática jurídica: uma abordagem a partir da Begriffsgeschichte de Reinhart Koselleck. In: RODRIGUEZ, José Rodrigo.; SILVA E COSTA, Carlos Eduardo Batalha; BARBOSA, Samuel Rodrigues (Orgs.). Nas fronteiras do formalismo: a função social da dogmática jurídica hoje. São Paulo: Saraiva, 2010, p. 36; Filosofia e teoria geral do direito: homenagem a Tercio Sampaio Ferraz Junior. São Paulo: Quartier Latin, 2011.

29 O "Primeiro tratado sobre o governo" é uma refutação da obra "O Patriarca" de Robert Filmer, enquanto o "Segundo tratado sobre o governo" versa sobre o que Locke considera ser a "verdadeira origem, extensão e objetivo do governo civil." BONAVIDES, Paulo. Do Estado liberal ao Estado social... Op. Cit. p. 46-47. BOBBIO, Norberto. Liberalismo y democracia. México: Fondo de Cultura Económica , p. 12; BOBBIO, Norberto. Liberalismo e democracia. Tradução Marco Aurélio Nogueira. São Paulo: Brasiliense, 2006, p. 12. Para a preservação da propriedade como motivo à formação da sociedade e para uma leitura crítica da sua influência no liberalismo, respectivamente, ver, por exemplo: MACPHERSON, Crawford Brough. The political theory of possessive individualism: Hobbes to Locke. Oxford: Oxford University Press, 1962, p. 197 e ss.; RITTSTIEG, Helmut. La proprietà come problema fondamentale. Studio sull'evoluzione del diritto mercantile. Trad. della Scuola di specializzazione in diritto civile dell'Università di Camerino, 15. Napoli: Edizione Scientifiche Italiane, 2000, p. 69-79.

30 Note-se que, no Segundo Tratado sobre o Governo Civil, Locke mobiliza dois sentidos diferentes para o termo "propriedade". Em um primeiro sentido, ela significa o direito à posse de bens e riquezas obtidos mediante o trabalho. Em um sentido mais abrangente, entretanto, o autor também Ihe associa, na referida obra, um outro sentido, que abrangeria "a vida, a liberdade, saúde e posses". Cf. LOCKE, John. Dois tratados sobre o governo. Tradução de Julio Fischer. São Paulo: Martins Fontes, 1998, p. 405 e ss. A respeito, ver, especialmente, a tese de MACPHERSON, Crawford Brough. The political theory of possessive individualism: Hobbes to Locke. Oxford: Oxford University Press, 1962, p.197 e ss, WEINREB, Lloyd L. Natural law and justice. Cambridge, Massachusetts: Harvard University Press, 1997, p. 79-80.

2011. Para uma crítica à perspectiva de Macpherson, ver: TUCK, Richard. Natural rights theories: their origin and development. Cambridge: Cambridge University Press, 1995, p. 2-3.

31 A respeito, Locke considera que "o fim maior e principal para os homens unirem-se em sociedades políticas e submeterem-se a um governo é, portanto, a conservação de sua propriedade." .LOCKE, John. Dois tratados sobre o governo. Tradução de Julio Fischer. São Paulo: Martins Fontes, 1998, p. 495. 
sua legitimidade por atacar a razão fundamental que justifica a formação do próprio Estado. Locke, ademais, defende expressamente o direito à resistência no caso de expropriação da propriedade pelo Estado, defensor dela per se.32

Esse ideário demonstra a grande importância de Locke para o liberalismo, notadamente pela delimitação proposta ao papel estatal e também no que diz respeito à promoção da liberdade e da propriedade. Tomando como base a advertência de que nunca se deve agir como um pai tende a cuidar de um filho, segundo Locke, não se pode confundir o escopo do poder civil organizado, materializado no Estado, com o paternalismo. É, aliás, nesse sentido que, na obra "Primeiro tratado sobre o governo civil", desenvolve sua crítica às teses de Robert Filmer. ${ }^{33}$ No "Segundo tratado sobre o governo civil" procura justamente "mostrar a diferença entre o soberano de uma sociedade política, um pai de família e o capitão de uma galera"34.

Fato é que, com a semente plantada, no decorrer dos séculos, a estruturação política inglesa chegou ao que atualmente denominamos "direito constitucional", dando estatura à "separação dos poderes", cristalizada por Locke, valendo registrar que o judiciário ainda não fora inserido na tripartição dos poderes, que contemplava o legislativo, o executivo e o federativo, com soberania do parlamento sobre os demais. Sem pretender realizar uma análise mais aprofundada do pensamento do autor, em termos gerais, pode-se afirmar que o mesmo atribui ao poder judiciário uma menor relevância. 35

O receio da indevida utilização do poder, em razão dos excessos perpetrados pelo regime absolutista, estimulou o francês Charles-Louis de Secondat, o Barão de Montesquieu, a engendrar um mecanismo para controlar as ações do soberano. O político-filósofo Montesquieu é considerado pai da "tripartição dos poderes", cuja construção permite dividir a soberania no formato "quem legisla não executa e não julga, e vice-versa". O julgador, desta feita, não cria as leis, não administraria o Estado, o ocorrendo com o gestor, que estaria sempre afastado das duas outras funções estatais. Montesquieu grafou em sua clássica obra De L'Esprit des Lois a crença de que todo aquele que exerce poder tende a dele abusar. Então, para coibir a tirania, propôs a divisão de atuação referida linhas atrás. Esse pensamento denota um afastamento

\footnotetext{
32 Cf. LOCKE, John. Dois tratados sobre o governo. Tradução de Julio Fischer. São Paulo: Martins Fontes, 1998, p. 559 e ss. A respeito, ver: NICOLA, 2006, p. 276-278; BOBBIO, Norberto. Liberalismo y democracia... Op. Cit. p. 13. Acerca do direito à resistência em Locke, ver, por exemplo: THOMAS, D. A. Lloyd. Locke on government. London: Routledge, 1995, p. 57-58; BOBBIO, Norberto. Locke e o direito natural. Tradução de Sérgio Bath. 2. ed. Brasília: Editora da Universidade de Brasília, 1998. p. 239-246.

33 Cf. LOCKE, John. Dois tratados sobre o governo. Tradução de Julio Fischer. São Paulo: Martins Fontes, 1998, p. 203-376; 379-380; 537-342.

34 Cf. LOCKE, John. Dois tratados sobre o governo. Tradução de Julio Fischer. São Paulo: Martins Fontes, 1998, p. 381.

35 Cf. LOCKE, John. Dois tratados sobre o governo. Tradução de Julio Fischer. São Paulo: Martins Fontes, 1998, p. 502-528. A respeito, ver também: BOBBIO, Norberto. Locke e o direito natural. Tradução de Sérgio Bath. 2. ed. Brasília: Editora da Universidade de Brasília, 1998. p. 231-238; BOBBIO, Norberto. Liberalismo y democracia... Op. Cit. p. 23- 24; BOBBIO, Norberto. Liberalismo e democracia... Op. Cit. p. 22; REDANO, 1931, p. 147, 153, 156. No que tange à preocupação sobre a atuação do poder político em termo diferenciado, como, por exemplo, o de um pai, ver: LOCKE, John. Dois tratados sobre o governo. Tradução de Julio Fischer. São Paulo: Martins Fontes, 1998, p. 380; 456-460.
} 
da teoria lockeana para se dirigir à prática, com a delimitação de atores e papéis muito bem delimitados. 36

Além da justificação de limitação de poder, a sua teoria serviu, por um grande período, de substrato inquestionável para o liberalismo burguês firmar-se como chavemestra do pensamento filosófico e político. Esse ideário sobreviveu em razão da necessidade de preenchimento de uma lacuna teórica social que demonstrasse sintonia com os clamores de parcela da sociedade detentora do poder. A "separação dos poderes" apareceu intrinsecamente relacionada aos valores liberdade, modernidade, constituição e desagravo à monarquia, em destaque naquele período da história. Curioso, outrossim, que o medo surgiu novamente em primazia nas preocupações de formação de um novo poder; sendo assim, propõe-se poder como limite ao próprio poder. 37

Os líderes da Revolução Francesa, vale lembrar, serviram-se do ideário de Montesquieu para justificar a divisão dos poderes, porém, no plano teórico, pode-se questionar se o filósofo almejou qualquer ato dessa natureza; além do mais, outorgou-se pelos revolucionários e, posteriormente, pelos próprios constitucionalistas, sentido ao texto em comento, em constantes assertivas onde se rotulam expressões não presentes em seu bojo, sendo, nesse contexto, muito mais hermenêuticas contaminadas pelo espírito liberal, do que mesmo novas luzes filosóficas. Exemplo emblemático dessa perspectiva é a própria divisão de poderes, pois Montesquieu nunca fez tal afirmação, apenas mencionou a separação de três funções de um mesmo poder. ${ }^{38}$

Diferentemente de Montesquieu, especialmente a rígida separação liberal que comandou o constitucionalismo durante séculos, a separação dos poderes tem papel de destaque no pensamento do filósofo Jean-Jacques Rousseau. Em termos esquemáticos, e assumidamente imprecisos, pode-se afirmar que, na perspectiva de Rousseau, um poder cria as normas, cujo conteúdo é justamente o caminho a ser seguido, e outro deve segui-lo fielmente. Um poder (legislativo) seria responsável por elaborar as diretrizes estatais as quais seriam concretizadas por um segundo poder (executivo).

\footnotetext{
36 A respeito, Montesquieu afirma que "il y a, dans chaque État, trois sortes de pouvoirs: la puissance législative, la puissance exécutrice des choses qui dépendent du droit des gens, et la puissance exécutrice de celles qui dépendent du droit civil." MONTESQUIEU, De l'esprit des lois. Paris: Flammarion, 2008. p. 244-245. BANDEIRA DE MELLO, 2008, p. 11-12. BONAVIDES, Paulo. Do Estado liberal ao Estado social... Op. Cit. p. 49; TARELLO, Giovanni. Storia della cultura giuridica moderna. Bologna: II Mulino, 1976, p. 287; ZAFFARONI, Eugenio Raul; TAVARES, Juarez. Poder Judiciário: crise, acertos e desacertos. São Paulo: Revista dos Tribunais, 1995, p. 82. No debate inglês, ver MACIVER, R. M. The modern State... Op. Cit. p. 365.

37 Conforme Montesquieu, "Iorsque dans la même personne ou dans le même corps de magistrature, la puissance législative est réunie à la puissance exécutrice, il n'y a point de liberté; parce qu'on peut craindre que le même monarque ou le même sénat ne fasse des lois tyranniques, pour les exécuter tyranniquement.". MONTESQUIEU, De l'esprit des lois. Paris: Flammarion, 2008. p. 245. BONAVIDES, Paulo. Do Estado liberal ao Estado social... Op. Cit. p. 70; TARELLO, Giovanni. Storia della cultura giuridica moderna... Op. Cit. p. 285-286. ZAFFARONI, Eugenio Raul; TAVARES, Juarez. Poder Judiciário: crise, acertos e desacertos, p. 82.

38 ARON, Raymond. As etapas do pensamento sociológico. Tradução de Sérgio Bath. São Paulo: Martins Fontes, 2002, p. 7-28; CHEVALLIER, Jacques. L'État. 2. ed. Paris: Dalloz, 2011, p. 50-52; COMTE-SPONVILLE, André. La philosophie. Paris: PUF, 2005, p. 101-102; ZAFFARONI, Eugenio Raul; TAVARES, Juarez. Poder Judiciário: crise, acertos e desacertos1995, p. 82-83. MACIVER, R. M. The modern State... Op. Cit. p. 367.
} 
São, portanto, dois poderes e não três. 39 Não bastasse isso, Rousseau fomentou, especialmente no livro "Do contrato social", a igualdade e a soberania popular. Dois valores ligados umbilicalmente: como os homens são iguais, todos teriam direito ao mesmo poder. A soma das parcelas de poder de cada cidadão resultaria na soberania. O Poder, por essa perspectiva filosófica, é justificado pela vontade popular única e exclusivamente, portanto, cairia por terra a sua defesa por meio da divindade e/ou da própria força física, comuns à época. 40 Por essa perspectiva teórica, os indivíduos passariam o seu poder - oriundo de urbe natural - e o receberiam parcialmente de volta, à guisa de direitos civis. ${ }^{41}$

Como se sabe, a base teórica de Rousseau também fomentou a ideologia revolucionária francesa. ${ }^{42}$ Entre outros trechos do seu pensamento, defendeu a tese de que não existiria uma ordem natural oriunda da natureza ou mesmo da divindade e por essa razão nada justificaria o rei como soberano absolutista. ${ }^{43}$ Aliás, considerando a abissal diferença entre subjugar uma multidão e reger uma sociedade, sublinhava que homem algum tem autoridade natural sobre os seus semelhantes e que a força não produz o direito, razão pela qual somente as convenções forneciam a base para a existência de uma autoridade legítima

39 Referindo-se ao "corpo político" engendrado pelo contrato social, Rousseau faz a seguinte afirmação : "on y distingue de même la force et la volonté; Celle-ci sous le nom de puissance législative, l'autre sous le nome de puissance exécutive. Rien ne s'y fait ou ne s'y doit faire sans leur concours." ROUSSEAU, Jean-Jacques. Du contrat social. Paris: Gallimard, 2001 , p. 217.

40 Nesse sentido, Rousseau afirma que "toute justice vient de Dieu, lui seul en est la source; mais si nous savions la recevoir de si haut nous n'aurions besoin ni de gouvernement ni de loix". ROUSSEAU, Jean-Jacques. Du contrat social. Paris: Gallimard, 2001 p. 217 , p. 200

41 Para essa questão, ver, particularmente, os dois primeiros livros que constituem a obra Du contrat social. Cf. ROUSSEAU, Jean-Jacques. Du contrat social. Paris: Gallimard, 2001, p. 217, p. 173-216. A respeito, ver também: BANDEIRA DE MELLO, Celso Antônio. Discricionariedade e controle jurisdicional. 2. ed. 9. tir. Malheiros: São Paulo, 2008, p. 11; BONAVIDES, Paulo. Do Estado liberal ao Estado social... Op. Cit. p. 50-51; NASCIMENTO, Milton Meira do. Rousseau: da servidão à liberdade. In: WEFFORT, Francisco (org.). Os Clássicos da Política. Os clássicos da política. São Paulo: Ática, 2003. p. 191-193; VILLAS BÔAS FILHO, Orlando. Jean-Jacques Rousseau: a supremacia da vontade geral, a unidade do corpo moral e coletivo e a sobrecarga ética do cidadão. Prisma Jurídico, São Paulo, v. 7, n. 1, p. 93-108, jan./jun. 2008. Ao debate proposto, interessa a seguinte transcrição de Rousseau: "Trouver une forme d'association qui défende et protège de toute la force commune la personne et les biens de chaque associé, et par laquelle chacun s'unissant à tous, n'obéisse pourtant qu'à lui même et reste aussi libre qu'auparavant?. Tel est le problème fondamental dont le contrat social donne la solution." ROUSSEAU, Jean-Jacques. Du contrat social. Paris: Gallimard, 2001, p. 182

42 É muito recorrente a associação de Rousseau à Revolução Francesa. Basta lembrar, por exemplo, a frase de Joseph Lakanal, segundo a qual "ce n'est pas le Contrat Social qui nous a expliqué la Révolution, c'est la Révolution que nous a expliqué le Contrat Social." De fato, a influência de Rousseau na Revolução Francesa foi significativa. Milton Meira Nascimento, por exemplo, ressalta a ressonância do pensamento de Rousseau no "Círculo Social" - uma associação revolucionária fundada em 1790 por Nicolas e Bonneville e Claude Fauchet, da qual fizeram parte, entre outros, Condorcet e Brissot. Referida associação exerceu forte influência na Revolução Francesa até a queda dos girondinos. NASCIMENTO, Milton Meira. O Círculo Social: esboço de uma teoria da opinião pública na Revolução Francesa. In: COGGIOLA, Oswaldo (Org.) A Revolução Francesa e seu impacto na América Latina. São Paulo: Nova Stella: Edusp; Brasília, DF: CNPq, 1990, p. 71-94. Acerca da relação das ideias de Rousseau com a Revolução Francesa, ver também HABERMAS, Jürgen. La souveraineté populaire comme procédure: un concept normatif d'espace public. Trad. Mark Hunyadi. Lignes - Revue trimestrielle - arts - littérature - Philosophie - Politique. Paris, n. 7 , p. 29-58, sept. 1989; GROETHUYSEN, Bernard. Philosophie de la Révolution française. Paris: Éditions Gallimard, 1996; OZOUF M. L’homme régénéré: essais sur la Révolution française. Paris: Éditions Gallimard,1989; SOBOUL, A. História da revolução francesa. Trad. Hélio Pólvora. Rio de Janeiro: Zahar, 1974. A respeito, ver também VILLAS BÔAS FILHO, Orlando. Jean-Jacques Rousseau: a supremacia da vontade geral, a unidade do corpo moral e coletivo e a sobrecarga ética do cidadão. Prisma Jurídico, São Paulo, v. 7, n. 1, p. 93-108, jan./jun. 2008

43 A respeito, ver Rousseau, especificamente o capítulo 2 do Livro I do Contrato Social, onde critica Grotius, Hobbes e Aristóteles. 
entre os homens. ${ }^{44}$ Para Rousseau, a ordem social seria fundada em convenções e o contrato social surgiria exatamente para que a soma das forças individuais garantisse os direitos de cada membro. Eis o grande motivo para a formação do "corpo moral e coletivo" que o autor designa de "corpo político" ou "República". Assim, por consequência lógica, a sua violação acarretaria o fim dessa sociedade. Desta feita, a soma das vontades individuais forma a vontade geral, a qual, munida de intuito de bem comum, deveria dirigir o "corpo moral e coletivo". ${ }^{45}$ Nesse mesmo contexto, o papel do magistrado como grande defensor da sociedade e dos bons costumes, consistiria em proteger a propriedade e os bens civis, com a advertência que não deve tolerar nenhum dogma contrário aos mencionados bens a serem defendidos. 46

No cenário das Américas, no ano de 1787, a Filadélfia sediou um dos últimos grandes debates cujo objetivo era (re)pensar o papel do Estado Federado, a Convenção Federal, a qual desembocou na nova Constituição para os Estados Unidos da América. Uma das temáticas enfrentadas dizia respeito à tripartição dos poderes. $O$ palco, além das reuniões de debate, foi a imprensa de Nova lorque, que, no ano seguinte, publicou textos assinados por Publius com o propósito de estimular os Estados a ratificarem o texto magno recém-criado. O conjunto desses ensaios recebeu o nome de "O Federalista", posteriormente, a autoria foi reconhecida a Alexander Hamilton, James Madison e John Jay, personalidades de grande destaque na história americana. 47

Nesse debate, a influência dos tradicionais filósofos foi marcante. Rousseau e Montesquieu foram citados nominalmente. Com veemência, destacou-se o lado negativo da personalidade do homem, em repetição à tese de que o detentor do poder tende a abusar do seu exercício. Com efeito, reclamou-se da criação de um Estado forte repleto de mecanismos de controle do poder e seus mandatários, tal qual a ideia de separação dos poderes em que um poder coibiria o outro e assim sucessivamente. Contudo, aqui, a intenção não é propriamente limitar, mas sim dividir o trabalho com a pretensão de aumentar a eficiência dos poderes. Solicitou-se, no entanto, total atenção à garantia da autonomia do poder judiciário, que estaria em perigo por não ter poderes

\footnotetext{
44 Sobre a origem convencional da autoridade legítima, Rousseau, ao refutar a autoridade natural de um homem sobre outro e a possibilidade de a força engendrar o direito, afirma que "restent donc les conventions pour base de toute autorité legitime parmi les hommes." ROUSSEAU, Jean-Jacques. Du contrat social. Paris: Gallimard, 2001, p. 177.

45 Cf. ROUSSEAU, Jean-Jacques. Du contrat social. Paris: Gallimard, 2001, p. 182-186. A respeito, ver : NICOLA, 2006, p. 302, 305307; NASCIMENTO, Milton Meira do. Rousseau: da servidão à liberdade. In: WEFFORT, Francisco (org.). Os Clássicos da Política. Os clássicos da política. São Paulo: Ática, 2003. p. 194, 196 e 199. Eros Roberto Grau aponta o predomínio da influência filosófica de Montesquieu para o direito pátrio em detrimento da doutrina de freios e contrapesos. GRAU, Eros Roberto. 0 direito posto e o direito pressuposto, p. 168: “Sua doutrina chega até nós a partir da exposição de Montesquieu, e não pela via da postulação norte-americana dos freios e contrapesos.

46 NICOLA, Ubaldo. Antologia ilustrada da Filosofia. Editora Globo: São Paulo, 2006, p. 278.

47 LIMONGI, Fernando Papaterra. "O Federalista": remédios republicanos para males republicanos. In: WEFFORT, Francisco (org.). Os Clássicos da Política. Os clássicos da política. São Paulo: Ática, 2003. p. 245-246; MACIVER, R. M. The modern State... Op. Cit. p. 366.
} 
de iniciativa. Com esse adrede, timidamente vale registrar, outorga-se à Suprema Corte o sacerdócio de conceder a última palavra na hermenêutica constitucional. 48

Anos antes, em 1776, na redação da declaração de independência das então colônias inglesas, em seguida denominadas de Estados Unidos da América, Thomas Jefferson afirmou que o fundamento dos governos é a salvaguarda dos direitos do homem, numa interpretação objetiva da natureza humana. 49

A Suprema Corte Americana também serviu de exemplo para a criação da Suprema Corte brasileira, logo após o Período Imperial, com a proclamação da República. A indicação da referência veio de Dom Pedro II, externada em conversa com Salvador de Mendonça e com Lafayette Rodrigues Pereira, quando ambos foram despedir-se na véspera da viagem oficial ao EUA. Mesmo com a queda do monarca, o ideário não perdeu força, ao contrário, seguiu adiante, com a adoção de algumas características da corte americana na Constituição brasileira de 1891.50

\section{UMA RELEITURA SISTÊMICA DA SEPARAÇÃO DOS PODERES}

A complexidade fomenta a contingência, tanto no plano estritamente social quanto no jurídico. 51 À medida que aumentam as hipóteses de escolhas, surgem muitos resultados possíveis. Hoje, escolhe-se a opção 1, amanhã, opta-se pela alternativa 2. Ambas com igual possibilidade de aplicação. Essa característica é típica das sociedades modernas, o que resulta na necessidade de uma estrutura social igualmente complexa. Trata-se de uma via de mão dupla: uma sociedade hipercomplexa como a atual reclama uma estrutura adequada para solvê-la. Em contrapartida, a estrutura da sociedade constituída em face das necessidades da complexidade precisa deste mesmo emaranhado para a sua evolução estrutural, visto que a constante provocação por novas opções faz com que o sistema social parcial emita novas comunicações com o condão de atender as demandas sociais. 52

\footnotetext{
48 LIMONGI, Fernando Papaterra. "O Federalista": remédios republicanos para males republicanos. LIMONGI, Fernando Papaterra. "O Federalista”: remédios republicanos para males republicanos. In: WEFFORT, Francisco (org.). Os Clássicos da Política. Os clássicos da política. São Paulo: Ática, 2003. p. 246, 249-252; HAMILTON, Alexander; MADISON, James; JAY, Jonh. The federalist papers. Trad. Cid Knipell Moreira. Mentor Book: New York, 2003, p. 272-275. Sobre a pretensão norte-americana de aumentar a eficiência dos poderes pela tripartição de poderes, ver GRAU, Eros Roberto. $\mathbf{O}$ direito posto e o direito pressuposto, p. 168: "[...]; para os federalistas norte-americanos, diversamente, ela está imediatamente voltada a otimização do desempenho das funções do Estado, fundando-se também no princípio da divisão do trabalho.".

49 CAPURSO, Marcello. Che cosa è lo Stato. Problemi e definizioni. Torino: Rai Radiotelevisione, 1966, p. 95.

50 RODRIGUES, Leda Boechat. História do Supremo Tribunal Federal. t. I. 2. ed. Rio de Janeiro: Civilização Brasileira, 1991. p. 11. No mesmo sentido, VIEIRA, Oscar Vilhena. Supremo Tribunal Federal. Jurisprudência política. 2. ed. São Paulo: Malheiros, 2002, p. 17-18.

51 Acerca dessa questão, ver, especialmente: LUHMANN, Niklas. Social systems. Tradução de John Bednarz Jr. e Dirk Baecker. Stanford, California: Stanford University Press, 1995, p. 187 e ss.; LUHMANN, Niklas. Essays on self-reference. New York: Columbia University Press, 1990, p. 80-85. A respeito, ver, especialmente: GONÇALVES, Guilherme Leite. Direito entre certeza e incerteza: horizontes críticos para a teoria dos sistemas. São Paulo: Saraiva, 2013, p. 209 e ss.

52 LUHMANN, Niklas. Sociologia do direito. Tradução Gustavo Bayer. Rio de Janeiro: Tempo Brasileiro, 1983. v. 1, p. 15; NEVES, Marcelo. Entre Têmis e Leviatã: uma relação difícil. São Paulo: Martins Fontes, 2006, p. 15-16. Sobre a estrutura como redutora
} 
Postas essas considerações, verifica-se que o direito enfrentará situações novas e em cenários sociais completamente diversos, com desafios difíceis, inimagináveis até, de tal modo que, dia após dia, a advertência assentada por Bobbio torna-se mais atual: “[...] uma coisa é falar dos direitos do homem, direitos sempre novos e cada vez mais extensos, e justificá-los com argumentos convincentes; outra coisa é garantir-lhes uma proteção efetiva [...]" e, ainda, "[...] à medida que as pretensões aumentam, a satisfação delas torna-se cada vez mais difícil".53

O direito nesse contexto fica com a tarefa de elevar a sua carga de abstração pela construção de uma elasticidade conceitual-interpretativa, a fim de abarcar hipóteses completamente heterogêneas por meio de reiteradas decisões, positivando-as a cada escolha. ${ }^{54}$ Esse processo de novas escolhas também será operado pelo particular, dentro da sua margem de poder, outorgada previamente pelo próprio sistema parcial em questão. Apesar disso, sempre que houver dissenso entre os jurisdicionados, quer pela prática de ilícito, quer pela discordância interpretativa do pactuado contratualmente, restará ao Estado-juiz o escopo de dizer o direito.

As decisões estatais, cotidianamente, deparam-se com o princípio da separação dos poderes, cuja apuração da sua dimensão é imprescindível, até porque, historicamente, nota-se que a sua implementação se deveu ao esforço teórico do constitucionalismo liberal, forjado por uma das possíveis exegeses da filosofia política de Montesquieu e com a inequívoca atuação política da burguesia. O objetivo era criar um equilíbrio entre os poderes, cada um com a sua função, mas limitando o exercício do outro e assim sucessivamente. Nesse movimento, um poder coibiria o outro, naturalmente. Tal engrenagem foi pensada com um só intento: proteger os interesses liberais do abuso do poder absoluto, mediante a divisão do próprio poder e, sobretudo, pelo constante choque do exercício de poderes. 55

Para Luhmann, os tribunais estão localizados no centro do sistema jurídico, enquanto a legislação e os contratos estão na periferia. ${ }^{56} \mathrm{Sem}$ embargo, todos fazem

da complexidade, ver FEBBRAJO, Alberto. Funzionalismo struturale e sociologia del diritto nell'opera di Niklas Luhmann. Milano: Giuffrè, 1975, p. 46-47.

53 BOBBIO, Norberto. L'età dei diritti. Torino: Giulio Einaudi, 1997, p. 63. No original: "Scendendo infine dal piano ideale a quello reale, altro é parlare di diritti dell'uomo, di diritti sempre nuovi e sempre piú estesi, e giustificarli com argomenti persuasivi, altro è assicurare loro uma protezione effetiva. A propósito sara bene fare ancora questa observazione: via via che le pretese aumentano, la loro soddisfazione diventa sempre piú difficile.".

54 LUHMANN, Niklas. Sociologia do direito... Op. Cit. p. 15. No viés da concretude das normas constitucionais, conferir NEVES, Marcelo. A constitucionalização simbólica. São Paulo: Martins Fontes, 2007, p. 83-86.

55 BIN, Roberto; PITRUZZELLA, Giovanni. Diritto costituzionale. 2. ed. Torino: G. Giappichelli, 2000, p. 75-80. Ainda, no atual cenário teórico italiano, a respeito do modelo constitucional do Estado Liberal, ver VIGNUDELLI, Aljs. Diritto costituzionale. Prolegòmeni Princìpi Dinamiche.Torino: G. Giappichelli, 1999. p. 40-41. No Brasil, indica-se BONAVIDES, Paulo. Do Estado liberal ao Estado social... Op. Cit. p. 63-88. Para um conceito de complexidade e de contingência, ver FEBBRAJO, Alberto. Funzionalismo struturale e sociologia del diritto nell'opera di Niklas Luhmann... Op. Cit. p. 43, 47-49.

56 Cf. LUHMANN, Niklas. El derecho de la sociedad. Traducción Javier Nafarrate Torres. 2. ed. Mexico: Universidad Iberoamericana, 2005, p. 359 e ss. A respeito, ver também: CAMPILONGO, Celso Fernandes. Política, sistema jurídico e decisão judicial. São Paulo: Max Limonad, 2002, p. 151 e ss.; VILLAS BÔAS FILHO, Orlando. Teoria dos sistemas e o direito brasileiro. São Paulo: Saraiva, 2009, p. 333 e ss.; GONÇALVES, Guilherme Leite; VILLAS BÔAS FILHO, Orlando. Teoria dos sistemas sociais: direito e 
parte do sistema, conhecido igualmente como sistema funcionalmente diferenciado, que possui função específica para atuar no sistema social global, marcado justamente pelo primado da diferenciação funcional. E sua identificação é exatamente a sua comunicação diferenciada, a materializar-se no seu código binário (lícito/ilícito) que baliza as operações comunicativas de tal sistema. A diferenciação comunicativa assume um papel-chave: sem ela não há subsistemas.

Com o propósito de criar um artefato capaz de auxiliar no bloqueio de eventual desdiferenciação, historicamente, a separação dos poderes se afigura como instrumento de fortalecimento da diferenciação comunicativa, consequentemente de inibição do abuso de poder. Aliás, para Luhmann, a diferenciação funcional representaria o próprio Estado Democrático de Direito porque garante a operação autônoma dos sistemas parciais em comento (política e direito) e não a autonomia da Administração Pública. 57

Nesse mesmo sentido teórico, o Estado tem sido gradativamente alterado conforme a própria complexidade social. O Estado constitucional é fruto da diferenciação do sistema político como reação interna, diante da hipercomplexidade, como forma de uma ordem política. ${ }^{58} \mathrm{O}$ Estado constitucional utiliza o direito, por meio da sua positivação, como autolimitação do abuso do poder. A separação dos poderes surgiu mesmo como limitador da força física do poder59; é o resultado da comunicação do processo reflexivo do sistema político, provocado pela irritação do mencionado sistema pelo abuso de poder, sobretudo aquele do Estado Absoluto, como fruto da positividade jurídica. 60

Nessa perspectiva, a evolução social é fomentada pela própria sociedade com o implemento de sua complexidade. ${ }^{61} \mathrm{Na}$ exata proporção da elevação da complexidade, os problemas vão surgindo e, com eles, novas operações sociais são inerentes ao próprio ambiente. Como frisa Luhmann, é uma relação dúplice: resolvem-se os problemas via novas comunicações e, paralelamente, surgem novos problemas delas decorrentes, o que impulsiona a diferenciação comunicacional. Tudo isso ocorre em razão da complexidade social. Desse processo, resulta a evolução, que não significa

sociedade na obra de Niklas Luhmann. São Paulo: Saraiva, 2013, p. 126 e ss.

57 NEVES, Marcelo. A constitucionalização simbólica, p. 80-83; LIMA, Fernando Rister de Souza. Sociologia do direito. O direito e o processo à luz da teoria dos sistemas de Niklas Luhmann. Curitiba: Juruá, 2009. p. 61-67; NEVES, Marcelo. Entre Têmis e Leviatã: uma relação difícil... Op. Cit. p. 85, 89- 91.

58 Acerca do sistema político na teoria dos sistemas de Luhmann, ver, por exemplo: KING, Michael; THORNHILL, Chris. Niklas Luhmann's theory of politics and law. Basingstoke: Palgrave Macmillan, 2003, p. 69 e ss.

59 Cf. LUHMANN, Niklas. Metamorfosi dello Stato. In: CEVOLINI, Alberto (Coord.). Potere e modernità. Stato, diritto, costituzione. Milano: Franco Angeli, 2007. p. 18-19.

60 Da mesma forma, pode-se dizer, em relação aos direitos humanos e fundamentais, LUHMANN, Niklas. Metamorfosi dello Stato. In: CEVOLINI, Alberto (Coord.). Potere e modernità. Stato, diritto, costituzione. Milano: Franco Angeli, 2007. p. 32.

61 A respeito, ver, especialmente: LUHMANN, Niklas. La sociedad de la sociedad. Tradução de Javier Torres Nafarrate. México: Herder, 2006, p. 100 e ss.; 325 e ss. A respeito, ver: GONÇALVES, Guilherme Leite. Direito entre certeza e incerteza: horizontes críticos para a teoria dos sistemas. São Paulo: Saraiva, 2013, p. 77 e ss. 
obrigatoriamente uma coisa boa, mas tão só que há um novo sentido dado à comunicação, ao menos se comparada à anterior.62

Ao transportar essa análise para o direito, percebe-se que em idêntica proporção da complexidade interna ao sistema vinda do externo, o subsistema em questão responderá com uma emissão comunicacional, isto é, processa-se a nova comunicação, que irritou o sistema, transformando-a em comunicação diferenciada com base no código binário: lícito/ilícito, em um processo operativo que resulta na própria positivação do direito. Por isso tudo, a positivação do direito, para Luhmann, é uma conquista evolutiva provocada pela elevação da complexidade; é fruto de um processo interno de reflexidade do sistema do direito, rotulado de reflexividade da normatização, concebida como mecanismo reflexivo ideológico, uma vez que reclama primeiro a valoração e depois a seleção.63

A mencionada reflexividade da normatização, obviamente interna ao sistema parcial do direito, torna-se um caso particular quando diferencia, pela comunicação, norma que servirá à formação de outras normas, dispostas na Constituição Federal. Segundo Luhmann, trata-se de uma padronização. ${ }^{64}$ Essa reflexividade, voltada ao princípio da separação dos poderes, mesmo quando enfrentada incidentalmente no julgamento do mérito do litígio, pode ser considerada como padronização nesse mesmo espírito apregoado pelo mencionado autor, quiçá quando praticada pela Suprema Corte.

O enunciado normativo, fruto desse processo, ao dar vida ao texto legal, tornase um ato de pura interpretação, cujo desenrolar pressupõe circularidade comunicativa. Seu resultado é incerto e possíveis conjecturas sobre a significação são meras expectativas, não obstante sempre estejam fixadas dentro da binariedade do respectivo código. Mesmo com tal complexidade, a concretização é imprescindível, uma vez que a ambiguidade/vagueza dos textos legais e a própria necessidade de levar a cabo os programas inseridos no direito reclamam a exegese da norma.

Ao aplicar a norma ao caso concreto, o julgamento fica responsável por proclamar o sentido da norma e a gerar o citado enunciado normativo, razão porque se chegou a rotular o magistrado de legislador. Para esta tese, o destaque é a constante

\footnotetext{
62 Cf.: LUHMANN, Niklas. La sociedad de la sociedad. Tradução de Javier Torres Nafarrate. México: Herder, 2006, p. 100 e ss.; 325 e ss. A respeito, ver também: FEBBRAJO, Alberto. Funzionalismo struturale e sociologia del diritto nell'opera di Niklas Luhmann, p. 92; VILLAS BÔAS FILHO, Orlando. O direito na teoria dos sistemas de Niklas Luhmann. São Paulo: Max Limonad, 2006, p. 102-103.

63 Cf. LUHMANN, Niklas. El derecho de la sociedad. Traducción Javier Nafarrate Torres. 2. ed. Mexico: Universidad Iberoamericana, 2005, p. 342; FEBBRAJO, Alberto. Funzionalismo struturale e sociologia del diritto nell'opera di Niklas Luhmann... Op. Cit. p. 95, 97, 99-100; NEVES, Marcelo. A constitucionalização simbólica. São Paulo: Martins Fontes, 2007, p. 132: "Pode-se, de acordo com o modelo sistêmico teórico, formular de maneira mais rigorosa: reflexividade como mecanismo no interior de um sistema autopoiético implica que o processo referente e o processo referido são estruturados pelo mesmo código binário e que, em conexão com isso, critérios e programas do primeiro reaparecem em parte no segundo. Por conseguinte, não é suficiente, por exemplo, indicar a normatização da normatização, pois a normatização religiosa ou moral da normatização jurídica, como também a referência normativa de um padrão de 'direito natural' à emissão de norma jurídico-positiva não representam, nesse sentido estrito, nenhuma reflexividade da produção normativa.".
}

64 FEBBRAJO, Alberto. Funzionalismo struturale e sociologia del diritto nell'opera di Niklas Luhmann, p. 100-101. 
dicotomia existente entre o legislador e o julgador. Há entre ambos uma dupla contingência (ou contingência social), na qual se encontram ego e alter, num incessante jogo comunicativo, a resultar numa incerteza quanto à compreensão da comunicação. A cognição de alter pode não coincidir com a intenção pretendida. O resultado, sem embargo, sempre deverá suscitar um sentido implícito "alter quis dizer isso".65

No decorrer do processo interpretativo, a complexidade e a contingência têm papel de destaque, conforme ressaltado, especialmente na exegese dos princípios. Nele, o jogo comunicativo alcança níveis mais elevados, inclusive chega às construções comunicativas do Estado moderno, completamente mutáveis, em cujo desenvolvimento sucede uma constante tensão entre programas normativos, valores morais e outros tantos critérios que, no momento decisório, influenciam o seu resultado.

Desse modo, a busca do sentido da norma constitucional pode alcançar altíssimos índices de contingência, a ponto de influenciar na incerteza social a respeito dos enunciados normativo-constitucionais. Obviamente, essa hermenêutica construtivista não pode resultar em choque ou negação do texto legal interpretado, nem considerá-lo um sistema unitário do direito, pois sua aplicação deve ter consonância com as demais normas, as de patamar constitucional especialmente, tudo para dar tornar o sistema harmônico e coeso, até porque sistema sem coesão e sem harmonia não é um sistema. 66

Ao aplicar esse pensamento aos princípios constitucionais, o intérprete se depara com um índice de profundidade reflexiva extremamente elevado, em efetivas estruturas de reflexividade, nas quais se constrói a observação de segunda ordem, cuja consequência lógica é a hermenêutica das regras em circularidade, que algumas vezes são interpretadas ampliativamente, demonstrando um nítido balizamento de conteúdo, como afirma Neves. Aliás, o autor faz menção ainda ao perigo dos extremos da reflexividade principiológica, pois se é verdade que regras rígidas demais podem chocar-se com uma sociedade complexa e extremamente dinâmica, também é verdade que o excesso pode diminuir, e até eliminar, a consistência teórica do direito, dando espaço à dominação de valores radicais com origem burguesa, religiosa ou de quaisquer grupos moralistas extremos. 67

\footnotetext{
65 Luhmann absorve da Teoria de Talcott Parsons a idéia de dupla contingência. A atribuição de sentido, quer nos sistemas psíquicos, quer nos sistemas sociais, sempre começará, pela elevada complexidade, a fluir também na elevada contingência, até a seletividade, com a diferenciação sistêmica, a resultar na própria formação dos sistemas. Sobre a dupla contingência (doppelte Kontingenz), no cenário italiano, ver CORSI, Giancarlo; ESPOSITO, Elena; BARALDI, Cláudio. Glosario sobre la teoria social de Niklas Luhmann. Tradução Miguel Romero Pérez y Carlos Villalobos. México: Universidad Ibero Americana, 1996. p. 67-68; no Brasil, ver LIMA, Francisco Rister de Souza. Sociologia do direito. O direito e o processo à luz da teoria dos sistemas de Niklas Luhmann. 2. ed. Curitiba: Juruá, 2012, p. 4.

66 Especialmente sobre a unidade do Direito, ver LIMA, Francisco Rister de Souza. Sociologia do direito. O direito e o processo à luz da teoria dos sistemas de Niklas Luhmann. 2. ed., p. 29-30. BOBBIO, Norberto. Teoria dell'ordinamento giuridico. Turino: G. Giappichelli Editore,1960. p. 69, 75. Por conseguinte, pode-se afirmar ser um pleonasmo a assertiva: sistema harmônico e coeso.

67 Dentro do mundo luhmanniano, a observação é, na verdade, uma operação que usa uma distinção para indicar os dois lados dessa mesma distinção. Segundo George Spencer Brown, a base de toda construção é a distinção. Sobre a observação
} 
Não é de estranhar que essa artificialidade garanta um espaço comunicativo para que existam decisões em sentido contrário emitidas por outros representantes do Estado-juiz, tampouco vislumbrar que no futuro a mesma autoridade reinterprete a regra antes enfrentada à luz do mesmo princípio, obtendo resultado diverso do primeiro caso julgado, em nítida materialização da dupla contingência. É claro que instabilidade em demasia pode gerar insegurança social e mesmo desprestígio do direito diante da sociedade. Esse é o risco do direito. Não é tarefa fácil construir um formato de sistema jurídico que garanta a resolução das emergentes e constantes demandas sociais, sem conceder ao hermeneuta, in casu ao magistrado, poderes de reflexividade outorgados propriamente pelos princípios.

Em virtude dessa alta artificialidade, positivaram-se os direitos fundamentais como garantia de uma possível desdiferenciação do direito face às possíveis interpretações, apta a priorizar, por exemplo, valores morais em desfavor de regras. Esta atitude pode desencadear o fortalecimento dos regimes autoritários, de forte apelo ditatorial, de modo que a funcionalidade sistêmica seja prejudicada quando direitos subjetivos são deixados de lado - como liberdade ou mesmo direitos inerentes à personalidade -, em favor de valores momentâneos, ditados pelo novo governo.68

Com fulcro no manancial teórico sistêmico, o legislador seria "alter" e o juiz estaria no lugar de "ego". Ter-se-ia a Assembleia Constituinte e a Corte Suprema ligadas comunicativamente com o seu subsistema de origem, respectivamente o político e o jurídico. ${ }^{69}$ Nestes termos, a interpretação de uma Constituição base de um Estado Democrático de Direito reclamaria um choque harmônico entre princípios e regras, constante, incessante, chegando ao fim apenas na decisão final, quando então fica evidente a posição tomada pelo intérprete, a resultar na circularidade da relação entre normas e princípios.

Antes disso, a Constituição Federal, como acoplamento estrutural entre os sistemas jurídico e político, propiciará uma forte e ininterrupta troca comunicativa entre ambos, quando um sistema influenciará o outro na tomada da decisão. ${ }^{70}$ No caso do direito, o processo comunicativo judicial primeiramente apresenta uma argumentação formal atrelada às regras, para depois adequá-la aos valores sociais sobrepesada com a retórica substantiva dos princípios, como enfatiza Neves. ${ }^{71}$

(Beobachtung), na doutrina italiana, ver CORSI Giancarlo; ESPOSITO, Elena; BARALDI, Cláudio. Glosario sobre la teoria social de Niklas Luhmann, p. 117-121.

68 A ideia da reflexividade sistêmica controlada está em sintonia com a autopoiese. Ver NEVES, Marcelo. Entre Têmis e Leviatã: uma relação difícil. São Paulo: Martins Fontes, 2006, p. 64-65.

69 Sobre a relação entre o sistema jurídico e o político, ver: El derecho de la sociedad. Traducción Javier Nafarrate Torres. 2. ed. Mexico: Universidad Iberoamericana, 2005, p. 473 e ss.

70 Sobre a constituição como acoplamento estrutural entre os sistemas jurídico e político, ver, especialmente: El derecho de la sociedad. Traducción Javier Nafarrate Torres. 2. ed. Mexico: Universidad Iberoamericana, 2005, p. 541 e ss.

71 Pontual é a citação do seguinte trecho retirado da página 156: "[...] Na relação entre alter (o legislador) e ego (o tribunal constitucional), cada um dos lados parte da linguagem e dos critérios de cada um dos sistemas a que estão primariamente 
A negação da dupla contingência por parte das Cortes Constitucionais não significa recusa do valor axiomático da norma constitucional. O inverso disso, o texto oriundo da interpretação também é produto do texto constitucional, tanto que se fala em "produção de textos com base em textos". Trata-se de um processo circular que suscita dos ministros do Supremo Tribunal Federal, diante da tese e da antítese trazidas aos autos pelas partes, a construção da síntese correspondente ao caso concreto julgado. O enunciado normativo que emerge da síntese é fruto dessa circularidade, visualizada pelo Estado-juiz, inicialmente em face de determinada realidade fática descrita nas peças processuais, para, em seguida, casá-la com um discurso formal, quer dizer; as regras do direito serão aplicadas à situação específica e, ao final, mesclar isso tudo com uma retórica substantiva, de ordem principiológica - note-se que os princípios aqui entram como tempero final, com o intuito de amoldar as arestas, e não o contrário.

Ainda sobre a sobreposição ao princípio da separação dos poderes: não poderia escusar a omissão judicial, notadamente diante da violação da função do sistema parcial do direito, o qual, segundo Luhmann, tem como escopo central a garantia das expectativas normativas ao longo do tempo, traduzido pela seguinte assertiva: o direito propiciará que a sociedade continue a acreditar na implementação do conteúdo das leis. A prova cabal dessa afirmação é o aumento vertiginoso do número de processos judiciais a cada ano. Em verdade, se não se confiasse no direito, o número de ações suscitando a tutela jurisdicional não se apresentaria em tais proporções.

O direito, entretanto, não conseguirá solver todos os problemas sociais, tampouco eliminará os dissabores de uma vida cotidiana tão complexa, sem um poder público pouco efetivo e completamente tomado pela corrupção sistêmica. Por essa razão, quando o julgador se depara com a separação dos poderes, no ato de julgar, como limitador da concretização de um direito, precisa servir-se da sociologia luhmanniana para lembrar primeiramente que os tribunais são os responsáveis pelo fechamento operacional do direito em face da desilusão: incumbidos de dizer se a conduta é conforme ou disforme ao direito. Ademais, deve questionar se sua perspectiva hermenêutica sobre a separação dos poderes e a respeito da legalidade atende a função do sistema do direito, precipuamente, garantir as expectativas normativas ao longo do tempo. Desse contexto, emerge a questão da politização do direito, que só ocorrerá com a sua hipertrofia em face da política, materializando a negação do código binário do direito em favor da binariedade da política. ${ }^{72}$

Portanto, sendo certo que um sistema submete o outro à sua decisão, a negação de tutela jurisdicional igualmente pode incorrer a politização referida anteriormente.

vinculados, a política e o direito. [...]".

72 Sobre a relação entre direito e política, ver, especialmente: LUHMANN, Niklas. El derecho de la sociedad. Traducción Javier Nafarrate Torres. 2. ed. Mexico: Universidad Iberoamericana, 2005, p. 473 e ss 
Cada sistema tem sua função bem definida. ${ }^{73}$ Para aferir com segurança até onde um sistema pode ir, neste ponto do estudo, é oportuno mapear a natureza da comunicação de determinado sistema, sua função, seus limites e sua relação com outros sistemas parciais, como no caso do princípio da separação dos poderes: política (Administração Pública).

Nos dias atuais, a unidade dos sistemas sociais parciais, como o direito, ocorre pela via da unidade comunicativa, reiterada sob uma só binariedade. Dito por outra forma, a constante emissão do código lícito/ilícito trará à tona o sistema do direito: um sistema parcial inserido no sistema social, a sociedade. Contudo, a quebra do código gera a sua corrupção, cuja reiteração leva à ruptura da unidade sistêmica. Em outro sentido, também é certo afirmar que os sistemas são funcionalmente diferenciados, ou seja, exercem uma função específica na sociedade. Conforme Luhmann, o sistema do direito tem a função de estabilizar as expectativas normativas mediante sua generalização congruente nas dimensões temporal, material e social.74 Por esse ideário, as comunicações sistêmicas devem ser emitidas, obviamente sob o respectivo código, com a pretensão de lutar pela credibilidade social das normas. Com a produção legislativa, valores morais foram institucionalizados e se transformaram em normas jurídicas, passando a constituir referência incontornável do sistema do direito a generalização congruente das expectativas normativas. ${ }^{75}$

As fronteiras do direito, traçadas exatamente pelo código do sistema lícito/ilícito (Recht/Unrecht), são materializadas na dicotomia luhmanniana sistema/ambiente, valendo lembrar que o sistema é uma "forma de dois lados" (Zwei-Seiten-Form). Por este plexo, para ser considerada comunicação do sistema do direito, há a irrenunciável necessidade de a comunicação ser diferenciada pelo código, sob pena de simplesmente não ser reconhecida como comunicação jurídica. Nesse mesmo diapasão, a relação com os outros sistemas parciais é comunicativa, cada qual com sua respectiva função e forma comunicativa diferenciada. É uma relação de igualdade, mas com funções bem definidas. O poder judiciário, inscrito nesse ambiente social hipercomplexo e contingente, no afã de solver os litígios, pode dar nova roupagem ao princípio da separação dos poderes. Aliás, o próprio Supremo Tribunal Federal já assentou que não se trata de um princípio oriundo do direito natural, imutável, mas como definido na Constituição Federal, passível de interpretação.76

\footnotetext{
73 No que concerne às funções desses dois subsistemas sociais, ver: LUHMANN, Niklas. El derecho de la sociedad. Traducción Javier Nafarrate Torres. 2. ed. Mexico: Universidad Iberoamericana, 2005, p. 473 e ss; KING, Michael; THORNHILL, Chris. Niklas Luhmann's theory of politics and law. Basingstoke: Palgrave Macmillan, 2003, p. 23 e ss.

74 Cf. LUHMANN, Niklas. El derecho de la sociedad. Traducción Javier Nafarrate Torres. 2. ed. Mexico: Universidad Iberoamericana, 2005, p. 188.

75 LIMA, Fernando Rister de Souza. Sociologia do direito. O direito e o processo à luz da teoria dos sistemas de Niklas Luhmann, 2. ed. p. 102; NEVES, Marcelo. Entre Têmis e Leviatã: uma relação difícil... Op. Cit. p. 10, 59, 60.

76 Para uma pontual constatação da evolução social das sociedades arcaicas às modernas, com menção à unidade comunicacional, ver NEVES, Marcelo. Entre Têmis e Leviatã: uma relação difícil... Op. Cit. p. 1-25, sobretudo, p. 23- 24. Ver também, LIMA, Fer-
} 
A esse respeito, Marcelo Neves afirma que, no Brasil, hodiernamente, haveria uma espécie de panaceia principiológica, quer no plano teórico, quer na jurisprudência, resultado da hipercomplexidade social e também da falta de consistência teórica da cultura jurídica brasileira. Para ele, haveria, ademais, um hábito de uso dos princípios, que, devido à grande quantidade de opções possíveis do processo de interpretação normativo, conduz à conclusão de que se reclama um julgador que saiba lidar com o choque comunicativo entre regras e princípios no momento da concretude da norma geral à norma individual. Com isso, repele-se a postura judicial de apego extremado a ambos, tanto em relação às regras quanto aos princípios; procedimento contrário levaria à inconsistência jurídica e/ou à inadequação social da decisão. Neves também critica o abuso da ponderação diante do caso concreto, em cujo excesso se escora, em seu entendimento, parte de respeitável doutrina - a constitucional e filosófica -, como tábua de salvação do direito quando mais parece o seu fim, pois deixaria nas mãos do aplicador uma espécie de "cheque em branco" para eliminar a consistência jurídica da decisão e, gradativamente, a sua legitimidade política.

$\mathrm{O}$ ato de julgar, como se sabe, envolve primeiramente a leitura atenta e detalhada dos fatos e só depois subsumi-los ao direito posto, normas constitucionais e infraconstitucionais, com destaque para as regras já positivadas que regulam diretamente ou por analogia a quaestio a ser dirimida. Esse é o momento de procurar o choque comunicativo com os princípios, aplicáveis ao caso, com o mote de serem guias interpretativos da realidade social - mesmo como um instrumento de adequação social com limites objetivos (as regras). Porém, os princípios não devem ser utilizados para desafiar a função sistêmica, consistente em garantir as expectativas normativas ao longo do tempo; ou seja, os princípios são guias e não poderão ser usados para desafiar a não concretude das normas sob o viés de que interessa à tese defendida. ${ }^{77}$

No âmbito da teoria dos sistemas, o poder é concebido como meio de comunicação simbolicamente generalizado. ${ }^{78}$ De fato, o poder acaba por transmitir uma complexidade reduzida, um caminho a ser seguido pelas próximas seleções. Poder é comunicação já com a complexidade reduzida e as próximas comunicações da sociedade,

nando Rister de Souza. Sociologia do direito. O direito e o processo à luz da teoria dos sistemas de Niklas Luhmann, p. 35-45 BRASIL. Supremo Tribunal Federal. MI 712/PA. Relator Ministro Eros Roberto Grau. Brasília, DF. Julgado em 25.10.2007. Publicado em 31.10.2008. Disponível em: <http://redir.stf.jus.br/paginadorpub/paginador.jsp?docTP=AC\&docID=558553>. Acesso em: 16 out. 2013: "41. Não há que se falar em agressão à 'separação dos poderes', mesmo porque é a Constituição que institui o mandado de injunção e não existe uma assim chamada 'separação dos poderes' provinda do direito natural. Ela existe, na Constituição do Brasil, tal como nela definida. Nada mais. [...]...

77 A tese é desenvolvida com base, inicialmente, numa metáfora mitológica entre o conflito de Hidra e Hércules, em que se elegeu o juiz lolau para resolver a questão. Sobre a generalização das expectativas, ver DI GIORGI, Raffaele. Scienza del diritto e legittimazione. Lecce: Pensa Multimedia, 1998, p. 229-232. Precisamente sobre as expectativas normativas, ver DI GIORGI, Raffaele. Scienza del diritto e legittimazione, p. 230, 233-236.

78 Citar livro do LUHMANN sobre poder. Citar tb. Verbete do dicionário do Arnaud e artigo do Tercio sobre poder. Para uma concisa análise sobre poder no pensamento de Luhmann, ver: CANAPARO, Claudio; FONSECA, Márcio Alves da; LEITE GONÇALVES, Guilherme; VILLAS BÔAS FILHO, Orlando. Pouvoir. In: ARNAUD, André-Jean (Dir.). Dictionnaire de la globalisation. Droit, science politique, sciences sociales. Paris: LGDJ, 2010, p. 415-418. 
pode-se dizer, serão por ela influenciadas. Por exemplo: "alter" (detentor do poder) adere a uma das possibilidades cabíveis ao caso; sua preferência poderá influenciar o "ego" (submisso ao poder) naquele caso específico e, além disso, impulsionar novas decisões. A relevância da compreensão dessa mensagem para a continuidade da cadeia comunicativa se estriba nestas máximas. Dessa interação estruturada, surge um símbolo que dá sustentação a uma unidade comunicativa, como expressão de unidade catalisada, com base em uma generalização simbólica potencializada, visível no tradicional esquema binário luhmanniano, espaço onde se organiza a interação dos valores com as operações binárias. ${ }^{79}$

A política opera com seu código comunicativo. Apesar disso, no Estado Democrático de Direito, o poder reclama de legitimidade quando exercido em desfavor da legalidade. Seu código binário une-se ao binarismo: legal/ilegal. Em razão dessa submissão à lei, garante-se a participação daqueles que não exercem o poder, como também se ordena a cooperação nas suas diferentes fontes. Acaba-se, assim, por obter um relativo consenso de valor. Sem embargo, muitas vezes, mesmo com seu exercício comunicativo, o poder carece de efetividade social e se torna dependente de outros fatores, de tal sorte que a coerção torna-se de grande valia nas situações de hipercomplexidade. Mais, o poder vinculado à norma jurídica apresenta-se como técnica de uma democracia a ser implementada sob a moralidade constitucional.

A respeito da Constituição Federal como subsistema do direito, há grande expectativa de os seus valores serem concretizados, não obstante as reiteradas desilusões. Significa dizer que, mesmo com o desrespeito aos seus comandos (constitucionais), cabe ao direito buscar, por meio de comunicações diferenciadas, a manutenção das expectativas normativas, mesmo que contrafactuais. Isso porque, esse é o grande mote do sistema parcial do direito, quiçá quando se depara com a norma das normas, responsável que é pelo fechamento operacional e talhada pela positividade moderna. Ainda assim, e talvez por essa mesma razão, o fim primordial do direito é a estabilização das expectativas, as quais, quando frustradas, provocam a reiteração comunicativa de decisões, pois, desse ponto em diante, o direito moderno é positivo e sua semântica se depara com o direito, introduzido por uma decisão e alterado por outra, propriamente num processo dinâmico e altamente contingente. 80

\footnotetext{
79 LUHMANN, Niklas. El derecho de la sociedad. Traducción Javier Nafarrate Torres. 2. ed. Mexico: Universidad lberoamericana, 2005, p. 5, 7, 11, 13, 14-16, 19, 48-49; MANSILLA, Darío Rodíguez. Introducción. In: LUHMANN, Niklas (Org.). Poder. Traducción Luz Mónica Talbot. Barcelona: Anthropos, 1995. p. XXV.

80 LUHMANN, Niklas. El derecho de la sociedad. Traducción Javier Nafarrate Torres. 2. ed. Mexico: Universidad lberoamericana, 2005, p. 69-70, 73, 114; NEVES, Marcelo. A constitucionalização simbólica... Op. Cit. p. 67 69-71; NEVES, Marcelo. Entre Têmis e Leviatã: uma relação difícil... Op. Cit. p. 87-95, 99-100, 192-193, 202, notadamente, p. 89:"No modelo teórico-sistêmico, o Estado de Direito pode ser definido, em princípio, como relevância da distinção entre lícito e ilícito para o sistema político. [...]" r p. 90 : "[...] Se, de um lado, o direito é posto basicamente por decisões políticas, de outro, a diferença entre lícito e ilícito passa a ser relevante para os órgãos políticos supremos, inclusive para os procedimentos eleitorais de sua escolha. [...]."e p. $95:$ :[...] O Estado de Direito não comporta a noção de poder arbitrário e, por isso mesmo, está sempre a enfrentar o problema do poder ilícito.".
} 
Nesse processo circular dos valores inseridos pela Constituição no direito, acrescido à rotineira troca de comunicação entre os tribunais, notadamente o Constitucional, e as demais comunicações sociais, sobressai uma perspectiva da autopoiese, traduzida nas comunicações diferenciadas que reproduzem a si mesmas e suas estruturas, num nítido espeque autopoiético, alimentado, nesse caso, pelas normas constitucionais e pela interpretação e aplicação a uma situação concreta, como acontece no caso do princípio da separação dos poderes, cuja exegese pode ocorrer ora em sentido restritivo, ora no âmago da concretude jurídico-social.

A norma constitucional, portanto, coloca-se como o grande limite cognitivo de aprendizagem da comunicação jurídica, e tudo a ela se submete. Por isso, as outras normas hão de ser o fruto de sua vontade, interpretadas por quem de direito. No caso brasileiro, o seu hermeneuta privilegiado é o Supremo Tribunal Federal. Nessa hipótese de Constituição descrita como limite sistêmico, como a concebe Luhmann, os direitos fundamentais (incluídos os sociais) são impostos ao sistema jurídico, na forma de garantias à desdiferenciação. 81 A partir da sua positivação, ao sistema político não mais caberia a opção política de efetivar tais direitos ou não, de forma que a Administração Pública, como parte do referido sistema, teria o ônus da sua efetivação social.

Nessa linha, quando eventual desilusão normativa em razão de desprestígio do texto constitucional pela gestão pública é submetida ao Estado-juiz, é ele quem se incumbirá da emissão de comunicação diferenciada, de modo a pretender o restabelecimento factual das expectativas não realizadas, sobretudo em função do princípio da separação de poderes. O Estado-juiz, nesse momento, assume o papel de limitador do poder político pela legalidade e responsável pela garantia do exercício do pluralismo dos poderes e da circularidade procedimental do Estado Democrático de Direito. Por essas digressões, ecoa o seu paradoxo: limita e garante, ao mesmo tempo, o poder. 82

\section{CONCLUSÃO}

Realizar uma releitura sistêmica do clássico princípio da separação dos poderes, como ponto de partida para realização do presente estudo, faz todo sentido quando se constata como real o contexto social hipercomplexo, que engendra uma nova configuração para a sociedade hodierna. Para dar conta dessa tarefa, foi necessário mobilizar, como referencial de análise, a teoria dos sistemas de Niklas Luhmann, que se inscreve

\footnotetext{
81 Cf.. LUHMANN, Niklas. El derecho de la sociedad. Traducción Javier Nafarrate Torres. 2. ed. Mexico: Universidad Iberoamericana, 2005, p. 548.

82 NEVES, Marcelo. A constitucionalização simbólica... Op. Cit. p. 71-78, 80-82, 105-106, 185-196. Em especial, ver p. 105: “[...] Através dela, o código do poder é associado ao código jurídico, procedimentos de decisão política são conduzidos pela via do direito. [...] Envolve, portanto, a realimentação circular entre legislação e jurisdição. [...].", p. 106: "[...] Por um lado, a especialização constitucional das funções limita juridicamente o poder, intensificando-o. Por outro, vincula o direito às decisões políticas, fortificando-lhe a autonomia. [...]", e p. 186: “Nesta perspectiva proponho uma releitura do discutível princípio da 'separação de poderes' como princípio da pluralidade e circularidade de procedimentos do Estado de Direito...
} 
no âmbito da matriz sociológica da diferenciação social e dá particular atenção à questão da fragmentação da sociedade contemporânea em diversos subsistemas funcionais, mostrando-se, desta feita, como a proposta teórica que maior aderência com o desvelo dessa questão. A primeira abordagem tratou de resgatar a classificação de Danilo Martuccelli acerca das sociologias da modernidade, justamente para sublinhar o quanto a concepção luhmanniana, inscrita que está no horizonte da matriz da diferenciação, é sensível aos problemas que decorrem da relação entre subsistemas funcionais distintos, no caso a política (enfocada pelo prisma da Administração Pública) e o direito (abordado, especialmente, pelos tribunais que, como visto, constituem o seu centro). Em seguida, realizou-se uma breve reconstrução das teorias clássicas que, na modernidade, contribuíram para a formulação e difusão do princípio da separação dos poderes. Neste ponto do estudo, com base no pensamento de Quentin Skinner, foi abordado o problema do anacronismo no campo da pesquisa histórica das ideias e destacada a importância da sua contextualização para solvê-lo. Feita essa análise, com esteio na teoria dos sistemas de Luhmann, realizou-se a releitura do princípio da separação dos poderes.

\section{REFERÊNCIAS}

ARON, Raymond. As etapas do pensamento sociológico. Tradução de Sérgio Bath. São Paulo: Martins Fontes, 2002.

BIN, Roberto; PITRUZZELLA, Giovanni. Diritto costituzionale. 2. ed. Torino: G. Giappichelli, 2000.

BANDEIRA DE MELLO, Celso Antônio. Discricionariedade e controle jurisdicional. 2. ed. 9. tir. Malheiros: São Paulo, 2008.

BOBBIO, Norberto. Liberalismo y democracia. México: Fondo de Cultura Económica, 1996.

BOBBIO, Norberto.L'età dei diritti. Torino: Giulio Einaudi, 1997.

BOBBIO, Norberto. Liberalismo e democracia. Tradução Marco Aurélio Nogueira. São Paulo: Brasiliense, 2006.

BOBBIO, Norberto. Locke e o direito natural. Tradução de Sérgio Bath. 2. ed. Brasília: Editora da Universidade de Brasília, 1998.

BOGNETTI, Giovanni. La divisione dei poteri. 2. ed. Milano: Giuffrè , 2001.

BONAVIDES, Paulo. Do Estado liberal ao Estado social. 7. ed. 2. tir. São Paulo: Malheiros, 2004.

BRASIL. Supremo Tribunal Federal. MI 712/PA. Relator Ministro Eros Roberto Grau. Brasília, DF. Julgado em 25.10.2007. Publicado em 31.10.2008. Disponível em: <http://redir.stf.jus.br/paginadorpub/paginador.jsp?docTP=AC\&docID=558553>. Acesso em: 16 out. 2013. 
CAMPILONGO, Celso Fernandes. Política, sistema jurídico e decisão judicial. São Paulo: Max Limonad, 2002.

CANAPARO, Claudio; FONSECA, Márcio Alves da; LEITE GONÇALVES, Guilherme; VILLAS BÔAS FILHO, Orlando. Pouvoir. In: ARNAUD, André-Jean (Dir.). Dictionnaire de la globalisation. Droit, science politique, sciences sociales. Paris: LGDJ, 2010. p. 415-418.

CAPURSO, Marcello. Che cosa è lo Stato. Problemi e definizioni. Torino: Rai Radiotelevisione, 1966. CHEVALLIER, Jacques. L'État. 2. ed. Paris: Dalloz, 2011.

CHIGNOLA, Sandro. História dos conceitos e história da filosofia política. In: FERES Jr., João; JASMIN, Marcelo Gantus (Org.) História dos conceitos: diálogos transatlânticos. Rio de Janeiro: Ed. da PUC-Rio: Edições Loyola: IUPERJ, 2007. p. 45-57.

COMTE-SPONVILLE, André. La philosophie. Paris: PUF, 2005.

CORSI, Giancarlo; ESPOSITO, Elena; BARALDI, Cláudio. Glosario sobre la teoria social de Niklas Luhmann. Tradução Miguel Romero Pérez y Carlos Villalobos. México: Universidad Ibero Americana, 1996.

DI GIORGI, Raffaele. Scienza del diritto e legittimazione. Lecce: Pensa Multimedia, 1998.

DERATHÉ, Robert. L'homme selon Rousseau. In: GENNETTE, Gérard; TODOROV, Tzvetan (Orgs.). Pensée de Rousseau. Paris : Éditions du Seuil, 1984. p. 109-124.

FEBRRAJO, Alberto. Funzionalismo struturale e sociologia del diritto nell'opera di Niklas Luhmann. Milano: Giuffrè, 1975.

FERES Jr., João. Para uma história conceitual crítica do Brasil: recebendo a Begriffsgeschichte. In: FERES Jr., João; JASMIN, Marcelo Gantus. (Org.) História dos conceitos: diálogos transatlânticos. Rio de Janeiro: Editora PUC-Rio: Edições Loyola: IUPERJ, 2007. p. 109-117.

GOLDSCHMIDT, Victor. Individu et communauté chez Rousseau. In: GENNETTE, Gérard; TODOROV, Tzvetan (Orgs.). Pensée de Rousseau. Paris : Éditions du Seuil, 1984. p. 147-161.

GONÇALVES, Guilherme Leite. Direito entre certeza e incerteza: horizontes críticos para a teoria dos sistemas. São Paulo: Saraiva, 2013.

;VILLAS BÔAS FILHO, Orlando. Teoria dos sistemas sociais: direito e sociedade na obra de Niklas Luhmann. São Paulo: Saraiva, 2013.

GRAU, Eros Roberto. O direito posto e o direito pressuposto. 3. ed. São Paulo: Malheiros, 2000. GROETHUYSEN, Bernard. Philosophie de la Révolution française. Paris: Éditions Gallimard, 1996. GUIBENTIF, Pierre. Teorias sociológicas comparadas e aplicadas. Bourdieu, Foucault, Habermas e Luhmann face ao direito. Revista Novatio luris, ano II, n. 3, p. 9-33, 2009. 
HABERMAS, Jürgen. Direito e democracia: entre facticidade e validade. Trad. Flávio Beno Siebeneichler. Rio de Janeiro: Tempo Brasileiro, 1997.

HABERMAS, Jürgen. La souveraineté populaire comme procédure: un concept normatif d'espace public. Trad. Mark Hunyadi. Lignes - Revue trimestrielle - arts - littérature - Philosophie - Politique, Paris, n. 7, p. 29-58, sept. 1989.

HAMILTON, Alexander; MADISON, James; JAY, Jonh. The federalist papers. Trad. Cid Knipell Moreira. Mentor Book: New York, 2003.

JASMIN, Marcelo Gantus. História dos conceitos e teoria política e social: referências preliminares. Revista brasileira de ciências sociais, São Paulo, v. 20, n. 57, p. 27-38, fev. 2005.

JASMIN, Marcelo Gantus; FERES Jr., João. História dos conceitos: dois momentos de um encontro intelectual. In: JASMIN, Marcelo Gantus; FERES Jr., João (Org.). História dos conceitos: dois momentos de um encontro intelectual: debates e perspectivas. Rio de Janeiro: Ed. da PUC-Rio: Edições Loyola: IUPERJ, 2006. p. 9-38.

KING, Michael; THORNHILL, Chris. Niklas Luhmann's theory of politics and law. Basingstoke: Palgrave Macmillan, 2003.

LIMA, Fernando Rister de Sousa. Sociologia do direito. O direito e o processo à luz da teoria dos sistemas de Niklas Luhmann. Curitiba: Juruá, 2009.

LIMA, Fernando Rister de Sousa. Sociologia do direito. O direito e o processo à luz da teoria dos sistemas de Niklas Luhmann. 2. ed. Curitiba: Juruá, 2012.

LIMONGI, Fernando Papaterra. "O Federalista": remédios republicanos para males republicanos. In:WEFFORT, Francisco (org.). Os Clássicos da Política. Os clássicos da política. São Paulo: Ática, 2003.

LOCKE, John. Dois tratados sobre o governo. Tradução de Julio Fischer. São Paulo: Martins Fontes, 1998.

LUHMANN, Niklas. Sociologia do direito. Tradução de Gustavo Bayer. Rio de Janeiro: Tempo Brasileiro, 1983. v. 1.

LUHMANN, Niklas. Essays on self-reference. New York: Columbia University Press, 1990.

LUHMANN, Niklas. El derecho de la sociedad. Traducción Javier Nafarrate Torres. 2. ed. Mexico: Universidad Iberoamericana, 2005.

LUHMANN, Niklas. Metamorfosi dello Stato. In: CEVOLINI, Alberto (Coord.). Potere e modernità. Stato, diritto, costituzione. Milano: Franco Angeli, 2007.

LUHMANN, Niklas. La sociedad de la sociedad. Traducción Javier Nafarrate Torres. México: Herder, 2006. 
LUHMANN, Niklas. Social systems. Translation John Bednarz Jr. e Dirk Baecker. Stanford, California: Stanford University Press, 1995.

MACIEL, Débora Alves; KOERNER, Andrei. Sentidos da judicalização da política: duas análises. Lua Nova, n. 57, p. 113-133, 2002.

MACIVER, R. M. The modern State. London: Oxford University Press, 1964.

MACPHERSON, Crawford Brough. The political theory of possessive individualism: Hobbes to Locke. Oxford: Oxford University Press, 1962.

MANSILLA, Darío Rodríguez. Introducción. In: LUHMANN, Niklas (Org.). Poder. Traducción Luz Mónica Talbot. Barcelona: Anthropos, 1995.

MARTUCCELLI, Danilo. Sociologies de la modernité. Paris: Gallimard, 1999.

MONTESQUIEU, De l'esprit des lois. Paris: Flammarion, 2008.

NASCIMENTO, Milton Meira. O Círculo Social: esboço de uma teoria da opinião pública na Revolução Francesa. In: COGGIOLA, Oswaldo (Org.) A Revolução Francesa e seu impacto na América Latina. São Paulo: Nova Stella: Edusp; Brasília, DF: CNPq, 1990. p. 71-94.

NASCIMENTO, Milton Meira do. Rousseau: da servidão à liberdade. In: WEFFORT, Francisco (org.). Os Clássicos da Política. Os clássicos da política. São Paulo: Ática, 2003.

NEVES, Marcelo. Entre Têmis e Leviatã: uma relação difícil. São Paulo: Martins Fontes, 2006.

NEVES, Marcelo. A constitucionalização simbólica. São Paulo: Martins Fontes, 2007.

NICOLA, Ubaldo. Antologia ilustrada da Filosofia. Editora Globo: São Paulo, 2006.

OZOUF, M. L’homme régénéré: essais sur la Révolution française. Paris: Éditions Gallimard, 1989. PIÇARRA, Nuno. A separação dos poderes como doutrina e princípio constitucional. Um conjunto para o estudo das suas origens e evolução. Coimbra: Coimbra, Faculdade de Direito de Lisboa, 1989.

RITTSTIEG, Helmut. La proprietà come problema fondamentale. Studio sull'evoluzione del diritto mercantile. Trad. della Scuola di specializzazione in diritto civile dell'Università di Camerino, 15. Napoli: Edizione Scientifiche Italiane, 2000.

RODRIGUES, Leda Boechat. História do Supremo Tribunal Federal. t. I. 2. ed. Rio de Janeiro: Civilização Brasileira, 1991.

ROUSSEAU, Jean-Jacques. Discours sur l'origine et les fondements de l'inégalité parmi les hommes. Paris: Gallimard, 1988.

ROUSSEAU, Jean-Jacques. Du contrat social. Paris: Gallimard, 2001.

SALDANHA, Nelson. O Estado moderno e a separação de poderes. São Paulo: Saraiva, 1987. 
SILVA, José Afonso da. Curso de direito constitucional positivo. 29. ed. São Paulo: Malheiros, 2007.

SKINNER, Q. Fundações do pensamento político moderno. Trad. Renato Janine Ribeiro e Laura Teixeira Motta. São Paulo: Companhia das Letras, 1996.

SKINNER, Q. The idea of negative liberty: philosophical and historical perspectives. In: SKINNER, Quentin; RORTY, Richard; SCHNEEWIND, Jerome B. (Eds.). Philosophy in history: essays on the historiography of philosophy. Cambridge: Cambridge University Press, 1998, p. 193-221.

SKINNER, Q. Liberty before liberalism. Cambridge: Cambridge University Press, 2000.

SOBOUL, A. História da revolução francesa. Trad. Hélio Pólvora. Rio de Janeiro: Zahar, 1974.

TARELLO, Giovanni. Storia della cultura giuridica moderna. Bologna: Il Mulino, 1976.

THOMAS, D. A. Lloyd. Locke on government. London: Routledge, 1995.

TUCK, Richard. História do pensamento político. In: BURKE, P. (Org.) A escrita da história: novas perspectivas. Trad. Magda Lopes. São Paulo: Ed. da Universidade Estadual Paulista, 1992. p. 273-289.

TUCK, Richard. Natural rights theories: their origin and development. Cambridge: Cambridge University Press, 1995.

VIEIRA, Oscar Vilhena. Supremo Tribunal Federal. Jurisprudência política. 2. ed. São Paulo: MaIheiros, 2002.

VIGNUDELLI, Aljs. Diritto costituzionale. Prolegòmeni Princìpi Dinamiche. Torino: G. Giappichelli, 1999.

VILLAS BÔAS FILHO, Orlando. $O$ direito na teoria dos sistemas de Niklas Luhmann. São Paulo: Max Limonad, 2006.

VILLAS BÔAS FILHO, Orlando. Jean-Jacques Rousseau: a supremacia da vontade geral, a unidade do corpo moral e coletivo e a sobrecarga ética do cidadão. Prisma Jurídico, São Paulo, v. 7, n. 1, p. 93-108, jan./jun. 2008.

VILLAS BÔAS FILHO, Orlando. Teoria dos sistemas e o direito brasileiro. São Paulo: Saraiva, 2009. VILLAS BÔAS FILHO, Orlando. A historicidade da dogmática jurídica: uma abordagem a partir da Begriffsgeschichte de Reinhart Koselleck. In: RODRIGUEZ, José Rodrigo.; SILVA E COSTA, Carlos Eduardo Batalha; BARBOSA, Samuel Rodrigues (Orgs.). Nas fronteiras do formalismo: a função social da dogmática jurídica hoje. São Paulo: Saraiva, 2010. p. 27-61.

VILLAS BÔAS FILHO, Orlando. A sociologia do direito: o contraste entre a obra de Émile Durkheim e a de Niklas Luhmann. Revista da Faculdade de Direito da USP, São Paulo, v. 105, p. 565-563, jan./dez. 2010. 
VILLAS BÔAS FILHO, Orlando. Différentiation fonctionnelle. In: ARNAUD, André-Jean (Dir.). Dictionnaire de la globalisation - Droit, science politique, sciences sociales. Paris: LGDJ, 2010.

VILLAS BÔAS FILHO, Orlando. Direito e liberdade: algumas considerações acerca de uma abordagem atenta à historicidade dos conceitos. In: BITTAR, Eduardo Carlos Bianca; ADEODATO, João Maurício (Orgs.). Filosofia e teoria geral do direito: homenagem a Tercio Sampaio Ferraz Junior. São Paulo: Quartier Latin, 2011. p. 917-941.

VILLAS BÔAS FILHO, Orlando. Democracia: a polissemia de um conceito político fundamental. Revista da Faculdade de Direito da USP, São Paulo, v. 108, p. 651-696, jan./dez. 2013.

VILLAS BÔAS FILHO, Orlando. A juridicização e a judiciarização enfocadas a partir da "sociologia política do direito" de Jacques Commaille. Revista brasileira de sociologia do direito, vol. 2, n. 2, p. 56-75, 2015.

VILE, M.J.C. Contitucionalismo y separación de poderes. Trad. Joaquín Varela Suanzes-Carpegna. Madrid: Centro de Estudios Políticos y Constitucionales, 2007.

WEINREB, Lloyd L. Natural law and justice. Cambridge, Massachusetts: Harvard University Press, 1997.

WOLKMER, Antonio Carlos. História do direito no Brasil. 4. ed. Rio de Janeiro: Forense, 2007.

ZAFFARONI, Eugenio Raul; TAVARES, Juarez. Poder Judiciário: crise, acertos e desacertos. São Paulo: Revista dos Tribunais, 1995. 